\title{
The Study of the Kinetics of Intramolecular Radical Cyclizations of Acylsilanes via the Intramolecular Competition Method
}

\author{
Weir-Torn J iaang, Hsien-Chang Lin, Kuo-H siang Tang, Lih-Bin Chang, and Yeun-Min Tsai* \\ Department of Chemistry, National Taiwan University, Taipe, Taiwan 106, Republic of China
}

Received October 15, 1998

\begin{abstract}
The kinetics of the radical cyclizations of acylsilanes is probed by the construction of an intramolecular competition system. In this system, known rate constants of ol efin cyclizations are used as the internal clock. At benzene reflux temperature $\left(80^{\circ} \mathrm{C}\right)$, the cyclization rate constants for 5-exo cyclizations of acylsilanes with primary radicals are on the order of $10^{6} \mathrm{~s}^{-1}$. The corresponding rate constants for 5-exo cyclizations with secondary radicals and 6-exo cyclizations with primary radicals lie on the order of $10^{5} \mathrm{~s}^{-1}$. The 6-exo cyclizations of acylsilanes with secondary radicals are slower and fall in the range of $10^{4} \mathrm{~s}^{-1}$. Substituents on the silicon of the acylsilanes affect the rates of cyclization. Large silyl groups reduce the rate, and this is more serious for the 6 -exo type of cyclizations. Electron-withdrawing groups increase the rates of cyclization.
\end{abstract}

\section{Introduction}

Intramolecular radical cyclization reactions have drawn the attention of synthetic chemists in recent years because of the wide range of synthetic utilities available through this methodology. ${ }^{1}$ An understanding of the kinetics and mechanistic aspects of these radical cyclization reactions will help the synthetic chemists to obtain better control of these processes. For this reason, the kinetics of radical cyclizations involving carbon-carbon multiple bonds have been extensively studied. ${ }^{2}$

The carbonyl functional group plays a central role in organic chemistry. Radical cyclizations involving carbonyls which produce cyclic alcohols were first reported in 1976 by Flies et al. $^{3}$ and later extensively studied by Fraser-Reid ${ }^{4}$ and others. ${ }^{5}$ F or example (eq 1 ), the cycliza-

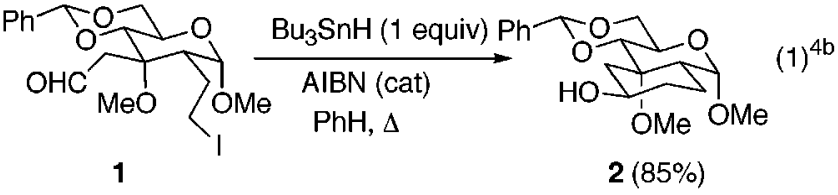

tion of $\epsilon$-iodo aldehyde $\mathbf{1}$ was reported to give al cohol $\mathbf{2}$ in $85 \%$ yield. ${ }^{4 b}$ Kinetic studies ${ }^{4 f, 6}$ of this type of cycliza-

* To whom correspondence should be addressed. Tel.: 886-2-23690152 ext 117. Fax: 886-2-2363-6359. E-mail: ymtsai@mail.ch.ntu. edu.tw.

(1) (a) Fossey, J .; Lefort, D.; Sorba, J. Free Radicals in Organic Chemistry; Wiley: New York, 1995. (b) Giese, B.; Kopping, B.; Göbel, T.; Dickhaut, J .; Thoma, G.; Kulicke, K.J .; Trach, F. Org. React. 1996, $48,301-856$.

(2) (a) Beckwith, A. L. J .; Ingold, K. U. In Rearrangements in Ground and Excited States; de Mayo, P., Ed.; Academic Press: New York, 1980; Vol. 1, pp 161-310. (b) Curran, D. P. In Comprehensive Organic Synthesis; Trost, B. M., Fleming, I., Eds.; Pergamon: New York, 1991; Vol. 4, pp 779-831. (c) Newcomb, M. Tetrahedron 1993, 49, 11511176.

(3) Flies, M. F.; Lalande, R.; Maillard, B. Tetrahedron Lett. 1976, 439-442.

(4) (a) Tsang, R. Fraser-Reid, B. J. Am. Chem. Soc 1986, 108 2116-2117. (b) Tsang, R.; Fraser-Reid, B. J . Am. Chem. Soc. 1986, 108, 8102-8104. (c) Tsang, R.; Dickson, J . K., J r.; Pak, H.; Walton, R.; Fraser-Reid, B. J . Am. Chem. Soc. 1987, 109, 3484-3486. (d) Fraser-Reid, B.; Vite, G. D.; Yeung, B.-W. A.; Tsang, R. Tetrahedron Lett. 1988, 29, 1645-1648. (e) Dickson, J . K.., J r.; Tsang, R.; Llera, J M.; Fraser-Reid, B. J . Org. Chem. 1989, 54, 5350-5356. (f) Walton, R.; Fraser-Reid, B. J . Am. Chem. Soc. 1991, 113, 5791-5799. tion quickly followed the synthetic work. As shown in Scheme $1,{ }^{6 b}$ Beckwith and $\mathrm{H}$ ay showed that the $\mathrm{k}_{1}$ value for 5-exo ring closure of 4-formylbutyl radical 3 is $8.7 \times$ $10^{5} \mathrm{~s}^{-1}$ at $80^{\circ} \mathrm{C}$. The $\mathrm{k}_{2}$ value for 6 -exo ring closure of 5 -formylpentyl radical 5 is $1.0 \times 10^{6} \mathrm{~s}^{-1}$ at $80^{\circ} \mathrm{C}$. The values of $k_{1}$ and $k_{2}$ are very close to the value of $k_{5-\text { exo }}$ $\left(1.4 \times 10^{6} \mathrm{~s}^{-1}\right.$ at $\left.80{ }^{\circ} \mathrm{C}\right)$ for 5-hexenyl radical $7 a .6 c, 7,8$ Interestingly, the 6-exo cyclization of 5-formylpentyl radical $\mathbf{5}$ is much faster than the corresponding cyclization of 6-heptenyl radical $\mathbf{7 b}$ which carries a $\mathrm{k}_{6 \text {-exo }}$ value of $4.3 \times 10^{4} \mathrm{~s}^{-1}$ at $80^{\circ} \mathrm{C} .{ }^{6 c, 7}$ The 5- and 6-exo cyclizations of alkenes are, in general, irreversible. ${ }^{7}$ In contrast, the cyclized cyclic alkoxy radicals $\mathbf{4}$ and $\mathbf{6}$ undergo facile $\beta$-scissions to give back the $\omega$-formyl radicals $\mathbf{3}$ and $\mathbf{5}$ with $\mathrm{k}_{-1}$ of $4.7 \times 10^{8} \mathrm{~s}^{-1}$ and $\mathrm{k}_{-2}$ of $1.1 \times 10^{7} \mathrm{~s}^{-1}$ at $80^{\circ} \mathrm{C}$, respectively. As compared with 4-formylbutyl radical 3, because of the faster rate of 6-exo cyclization of 5-formylpentyl radical $\mathbf{5}$ and the slower rate of $\beta$-scission of cyclohexyloxy radical $\mathbf{6}$, the cyclohexanol formation is generally more efficient. ${ }^{4}$

Recently Curran and co-workers ${ }^{9}$ devel oped the radical cyclizations of acylgermanes. As shown in Scheme 2, in the acylgermane system, radicals $\mathbf{1 0}$ derived from the corresponding $\omega$-iodo acylgermanes $\mathbf{9}$ cyclize to give $\beta$-germyl cycloalkoxy radicals $\mathbf{1 1}$. Due to the presence of

(5) (a) Paquette, L. A.; Ra, C. S.; Silvestri, T. W. Tetrahedron 1989, 45, 3099-3106. (b) Knapp, S.; Gibson, F. S.: Choe, Y. H. Tetrahedron Lett. 1990, 38, 5397-5400. (c) Knapp, S.; Gibson, F. S. J . Org. Chem. 1992, 57, 4802-4809. (d) Grissom, J. W.; Klingberg, D. J . Org. Chem. 1993, 58, 6559-6564. (e) Grissom, J. W.; Klingberg, D.; Meyenburg S.; Stallman, B. L. J . Org. Chem. 1994, 59, 7876-7888. (f) Clive, D. L. J .; Postema, M. H. D. J . Chem. Soc., Chem. Commun. 1993, 429-430. (g) J ung, M. E.; Choe, S. W. T. Tetrahedron Lett. 1993, 34, 6247-6250. (h) Hays, D. S.; Fu, G. C. J . Am. Chem. Soc. 1995, 117, 7283-7284. (i) Davin, P.; Fensterbank, L.; Malacria, M. Tetrahedron Lett. 1998, 39, 833-836.

(6) (a) Beckwith, A. L. J .; Hay, B. P. J . Am. Chem. Soc. 1989, 111, 230-234. (b) Beckwith, A. L. J .; Hay, B. P. J . Am. Chem. Soc. 1989 111, 2674-2681. (c) Beckwith, A. L. J .; Raner, K. D. J . Org. Chem. 1992, 57, 4954-4962.

(7) Beckwith, A. L. J . Tetrahedron 1981, 37, 3073-3100.

(8) Lusztyk, J .; Maillard, B.; Deycard, S.; Lindsay, D. A.; Ingold, K. U. J. Org. Chem. 1987, 52, 3509-3514.

(9) (a) Curran, D. P.; Liu, H. J . Org. Chem. 1991, 56, 3463-3465. (b) Curran, D. P.; Palovich, M. Synlett 1992, 631-632. (c) Curran, D. P.; Diederichsen, U.; Pal ovich, M. J . Am. Chem. Soc. 1997, 119, 47974804. (d) Diederichsen, U.; Curran, D. P. J . Organomet. Chem. 1997 $531,9-12$. 
Scheme 1<smiles>CCCCC=O</smiles>

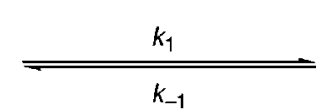

$k_{1}=8.7 \times 10^{5} \mathrm{~s}^{-1}\left(80^{\circ} \mathrm{C}\right)$

$k_{-1}=4.7 \times 10^{8} \mathrm{~s}^{-1}\left(80^{\circ} \mathrm{C}\right)$
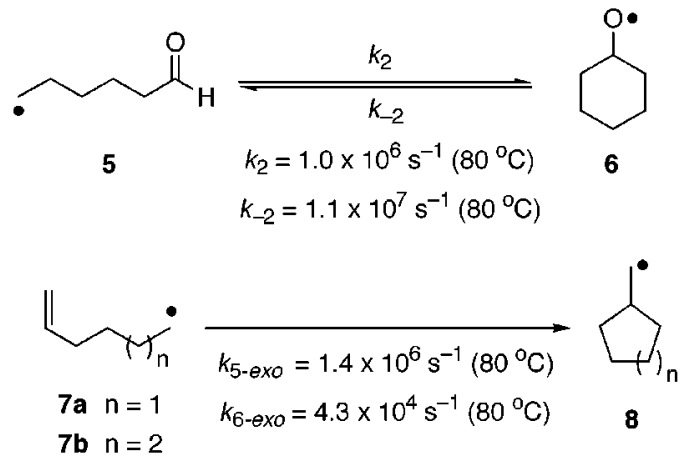

Scheme 2

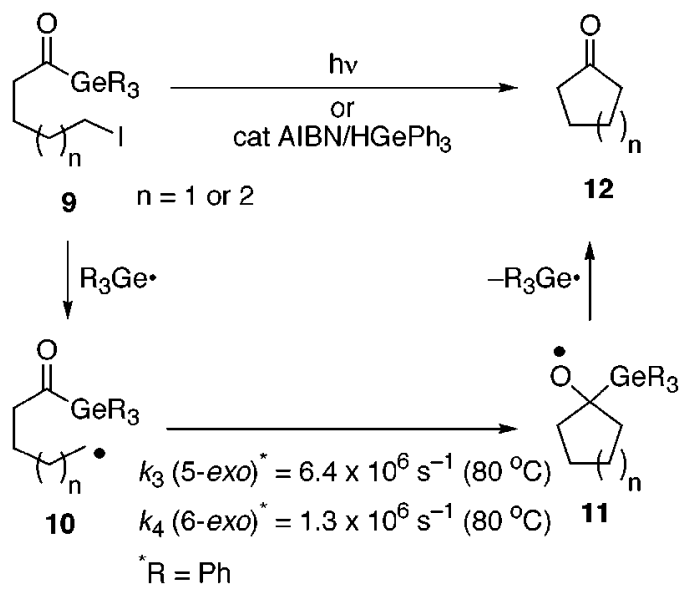

the $\beta$-germyl group, the alkoxy radicals $\mathbf{1 1}$ quickly undergo a $\beta$-scission reaction to generate the cyclic ketones $\mathbf{1 2}$, with concomitant formation of a germyl radical. The germyl radical reacts with the iodides $\mathbf{9}$, constituting a unimolecular chain transfer (UMCT) reaction. ${ }^{10}$ In the case of acyltriphenylgermanes, ${ }^{\text {9c }}$ the rate constants of 5-exo cyclization $\left(\mathrm{k}_{3}=6.4 \times 10^{6} \mathrm{~s}^{-1}\right.$ at $\left.80^{\circ} \mathrm{C}\right)$ and 6-exo cyclization $\left(\mathrm{k}_{4}=1.3 \times 10^{6} \mathrm{~s}^{-1}\right.$ at $\left.80^{\circ} \mathrm{C}\right)$ are very close to the corresponding $k_{1}$ and $k_{2}$ (Scheme 1 ) for $\omega$-formylalkyl radicals $\mathbf{3}$ and $\mathbf{5}$, respectively. For 5-hexenyl radical cyclizations, it is well-known that an alkyl substituent at $\mathrm{C}(5)$ severely reduces the rate of 5-exo cyclizations. ${ }^{7,11}$ To our knowledge, 5- and 6-exo cyclizations of ketones to give tertiary cyclic alcohols are rare and can only be realized in rigid skeletons. ${ }^{5 a}$ Therefore, the highly efficient radical cyclizations of germyl ketones are quite extraordinary. Variation of the substituents on the germanium of the acylgermanes effects the cyclization rate. $^{9 c}$ In general, an aryl substituent with an electronwithdrawing group at the para position is the most efficient. The substitution on the carbon that carries the initial radical also effects the cyclizations. ${ }^{9 c}$ Primary radicals undergo cyclization faster.

(10) (a) Curran, D. P.; Xu, J .; Lazzarini, E. J . Am. Chem. Soc. 1995 117, 6603-6604. (b) Curran, D. P.; Xu, J. Y.; Lazzarini, E. J . Chem Soc., Perkin Trans. 1 1995, 3049-3059.

(11) Beckwith, A. L. J .; Blair, I. A.; Phillipou, G. Tetrahedron Lett. 1974, 2251-2254.
Scheme 3
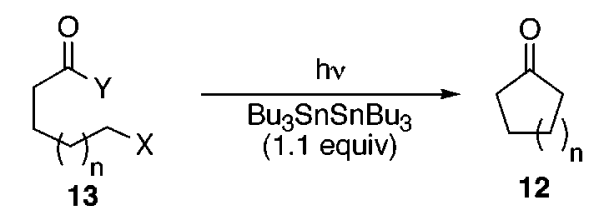

$\mathrm{n}=1$ or 2

$\mathrm{X}=\mathrm{Br}$ or $\mathrm{I}$

$Y=$ SPh or SePh

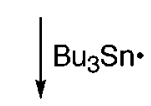<smiles>CC(C)C1CCCCC1=O</smiles>

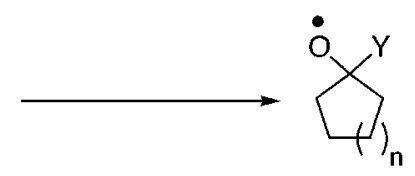

14

15

Scheme 4

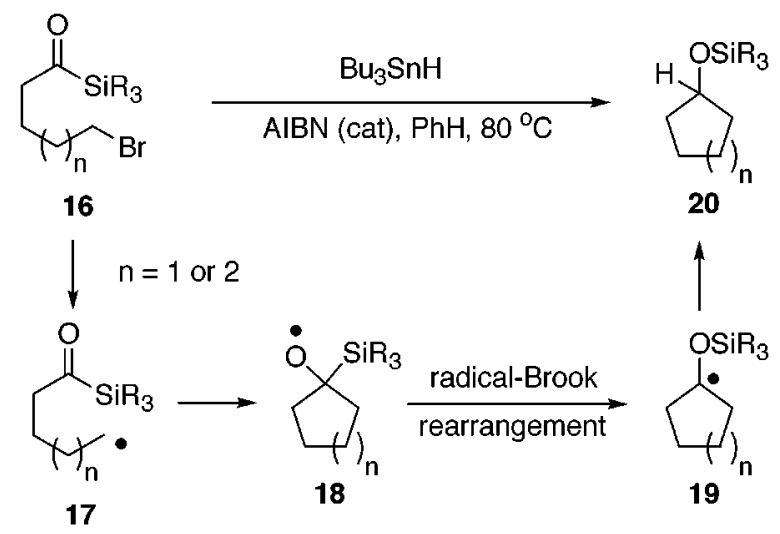

$\mathrm{Kim}$ and $\mathrm{J}$ on ${ }^{12}$ reported the radical cyclizations of thioesters and selenoesters $\mathbf{1 3}$ (Scheme 3). Radicals 14 generated from $\mathbf{1 3}$ cyclize to give alkoxy radicals $\mathbf{1 5}$. $\beta$-Scission of $\mathbf{1 5}$ gives cyclic ketones $\mathbf{1 2}$ with the formation of thio or seleno radicals which cannot react with the starting halides $\mathbf{1 3}$ to obtain radicals $\mathbf{1 4}$. Therefore, 1.1 equiv of hexabutylditin is required in this system. Although the kinetics in this system is not reported, it is known that with 1,2-migrations of radicals thioester groups migrate $10^{4}$ times slower than acyl groups. ${ }^{13}$

As shown in Scheme 4, we studied intramolecular radical cyclizations of acylsilanes. ${ }^{14}$ Radicals $\mathbf{1 7}$ derived from acylsilane $\mathbf{1 6}$ cyclized to give $\beta$-silyl alkoxy radicals 18. Contrary to the germyl, thio, and seleno analogues, the $\beta$-silyl alkoxy radicals $\mathbf{1 8}$ undergo radical-Brook rearrangement ${ }^{15}$ to afford $\alpha$-silyloxy radicals 19 . The final

(12) Kim, S.; J on, S. Y. J . Chem. Soc., Chem. Commun. 1996, 13351336

(13) (a) Giese, B.; Heinrich, N.; Horler, H.; Koch, W.; Schwarz, H. Chem. Ber. 1986, 119, 3528-3835. (b) Wollowitz, S.; Halpern, J. J . Am. Chem. Soc. 1984, 106, 8319-8321. (c) Wollowitz, S.; Halpern, J. J . Am. Chem. Soc. 1988, 110, 3112-3120. (d) Lindsay, D. A.; Lusztyk, J .; Ingold, K. U. J . Am. Chem. Soc. 1984, 106, 7087-7093.

(14) (a) Tsai, Y.-M.; Cherng, C.-D. Tetrahedron Lett. 1991, 32, 35153518. (b) Tsai, Y.-M.; Tang, K.-H.; J iaang, W.-T. Tetrahedron Lett. 1993, 34, 1303-1306. (c) Curran, D. P.; J iaang, W.-T.; Palovich, M.; Tsai, Y.-M. Synlett 1993, 403-404. (d) Tsai, Y.-M.; Chang, S.-Y. J . Chem. Soc., Chem. Commun. 1995, 981-982. (e) Chuang, T.-H.; Fang, J .-M.; J iaang, W.-T.; Tsai, Y.-M. J . Org. Chem. 1996, 61, 1794-1805. (f) Tsai, Y.-M.; Tang, K.-H.; J iaang, W.-T. Tetrahedron Lett. 1996, 37, 7767-7770. (g) Tsai, Y.-M.; Nieh, H.-C.; Pan, J.-S.; Hsiao, D.-D. J . Chem. Soc., Chem. Commun. 1996, 2469-2470. (h) Chang, S.-Y.; J iaang, W.-T.; Cherng, C.-D.; Tang, K.-H.; Huang, C.-H.; Tsai, Y.-M. J. Org. Chem. 1997, 62, 9089-9098. 
Scheme 5

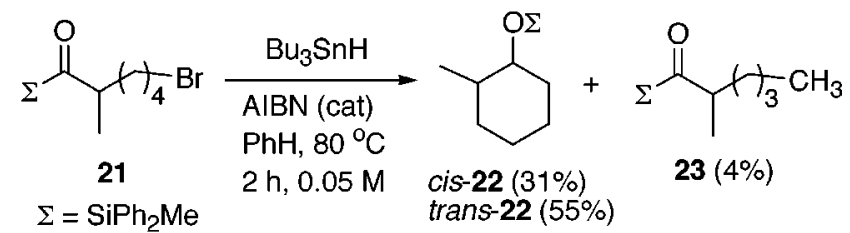

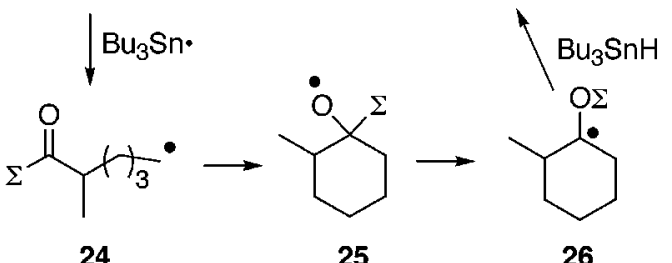

24

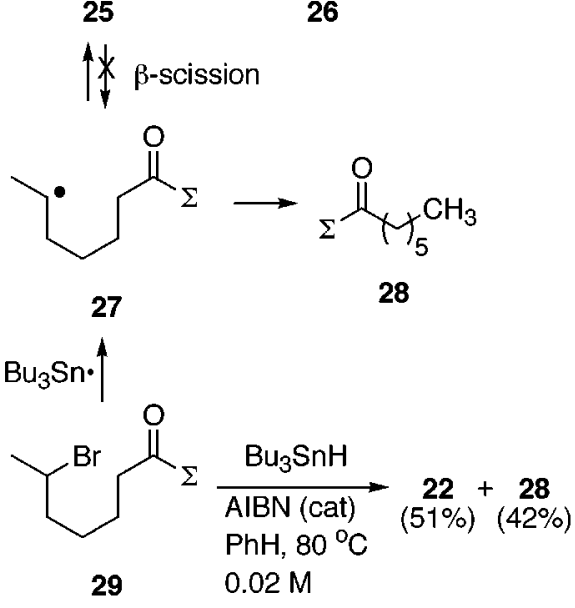

products of this process are cyclic silyl ethers 20. With the development of this interesting reaction, it is essential to study the mechanism and kinetics of the process. In a recent paper, ${ }^{14 \mathrm{~h}}$ we have described the qualitative aspect of this cyclization reaction. In this paper, we report the quantitative aspect of this reaction.

\section{Results and Discussion}

The Reversibility of Cyclization. As mentioned above, the $\omega$-formyl radical cyclizations are reversible. To know whether the $\beta$-silyl alkoxy radicals 18 will undergo $\beta$-scission to give the $\omega$-silylcarbonyl radicals $\mathbf{1 7}$ or not, we studied the cyclization of acylsilane $\mathbf{2 1}$ (Scheme 5). When $\mathbf{2 1}$ was treated with tributyltin hydride (1.2 equiv) in refluxing benzene in the presence of a catalytic amount of AIBN (0.05 equiv) as initiator, we obtained cyclic silyl ethers cis-22 (31\%) and trans-22 (55\%) as the major products. The uncyclized debrominated acyl silane 23 was isolated in $4 \%$ yield.

In this system, the $\omega$-silylcarbonyl radical $\mathbf{2 4}$ was generated from the cyclization substrate $\mathbf{2 1}$ and cyclized to give the $\beta$-silyl alkoxy radical intermediate 25 . If this cyclization is reversible, then there are two possible routes for $\beta$-scission of alkoxy radical $\mathbf{2 5}$. One route will give back the original primary radical $\mathbf{2 4}$, while the other route will generate the more stable secondary radical 27. In our previous work, ${ }^{14 \mathrm{~h}}$ we found that secondary radicals undergo 6-exo cyclizations with acylsilanes less efficiently than primary radicals and more uncyclized reduction

(15) (a) Dalton, J . C.; Bourque, R. A. J . Am. Chem. Soc. 1981, 103 699-700. (b) Harris, J. M.; Madlnnes, I.; Walton, J . C.; Maillard, B. J Organomet. Chem. 1991, 403, C25-C28. (c) Tsai, Y.-M.; Ke, B.-W. J . Chin. Chem. Soc. (Taipei) 1993, 40, 641-642. (d) Robertson, J .; Burrows, J . N. Tetrahedron Lett. 1994, 35, 3777-3780.

\section{Scheme 6}
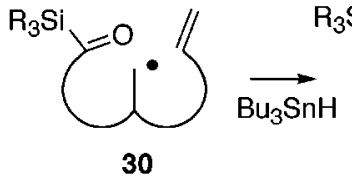

$\mathrm{R}_{3} \mathrm{SiO}$

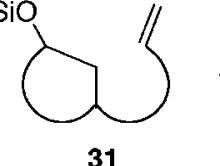

$\mathrm{C}=\mathrm{O}$ addition product

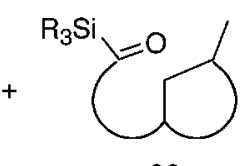

32

$\mathrm{C}=\mathrm{C}$ addition product
Radical clocks available:

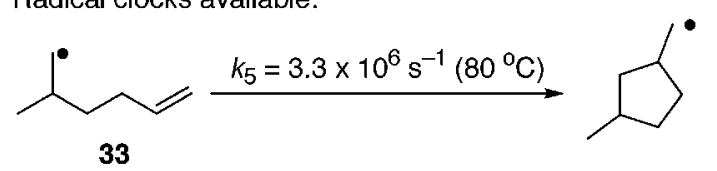

ref 17
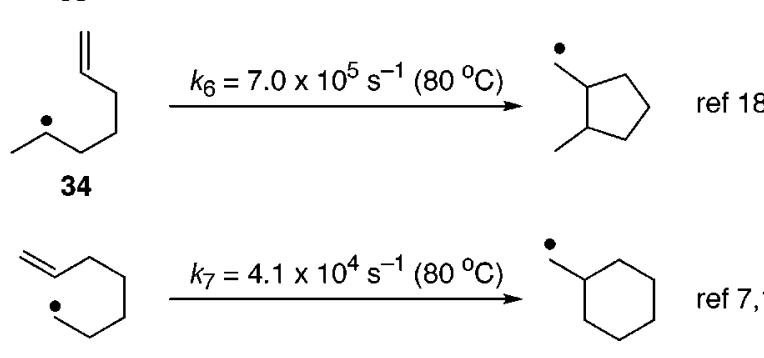

ref 7,19

products are obtained with these cyclizations. For example, the secondary bromi de $\mathbf{2 9}$ gave 6 -exo cyclization product 22 in $51 \%$ yield along with $42 \%$ of reduction product acylsilane $\mathbf{2 8}$. $^{14 \mathrm{~h}} \mathrm{~N}$ ote that a more dilute condition $(0.02 \mathrm{M})$ was used for cyclization of secondary bromide $\mathbf{2 9}$ than for that of primary bromide $\mathbf{2 1}(0.05$ $\mathrm{M})$. Therefore, if the cyclization of primary radical $\mathbf{2 4}$ is reversible, one would expect to observe the straight-chain acylsilane $\mathbf{2 8}$ derived from secondary radical $\mathbf{2 7}$. Since we did not observe any crossover reduction product from the cyclization of primary bromide $\mathbf{2 1}$, we concluded that the cyclization step is not reversible.

Harris et al. recently reported the EPR experiments on 1,2-migration of the trimethylsilyl group from carbon to oxygen. ${ }^{15 b}$ They found that the radical-Brook rearrangement occurs very rapidly at a temperature as low as $190 \mathrm{~K}$. It is likely that, once $\beta$-silyl alkoxy radical 25 is formed, the potential $\beta$-scission process is overwhelmed by the extremely facile silyl migration. As a result of the high $\mathrm{Si}-\mathrm{O}$ bond strength, ${ }^{16}$ the silyl migration is most likely irreversible and serves as an excellent thermodynamic driving force for the radical cyclizations of acylsilanes.

Construction of I ntramolecular Competition Systems. To probe the kinetics of the radical cyclizations of acylsilanes, we decided to use the intramol ecular competition systems ${ }^{2 \mathrm{c}}$ such as radical $\mathbf{3 0}$ shown in Scheme 6 as our tools. In 30, the radical could cyclize with the acylsilane or the olefin. As mentioned above, the radical addition to acylsilane carbonyl is determined to be irreversible. $^{7}$ The radical cyclization of an unstabilized radical with an olefin is also known to be irreversible. Therefore, the ratio of the $\mathrm{C}=\mathrm{O}$ addition product 31 relative to the $\mathrm{C}=\mathrm{C}$ addition product 32 should reflect the ratio of the cyclization rate constants of the two processes. In the literature, there are many fundamental radical cyclization rate constants available. ${ }^{2} \mathrm{~F}$ or example, the rate constants $k_{5}-k_{7}$ for the cyclizations of radicals

(16) J ackson, R. A. J . Organomet. Chem. 1979, 166, 17-19. 


\section{Scheme $7^{a}$}
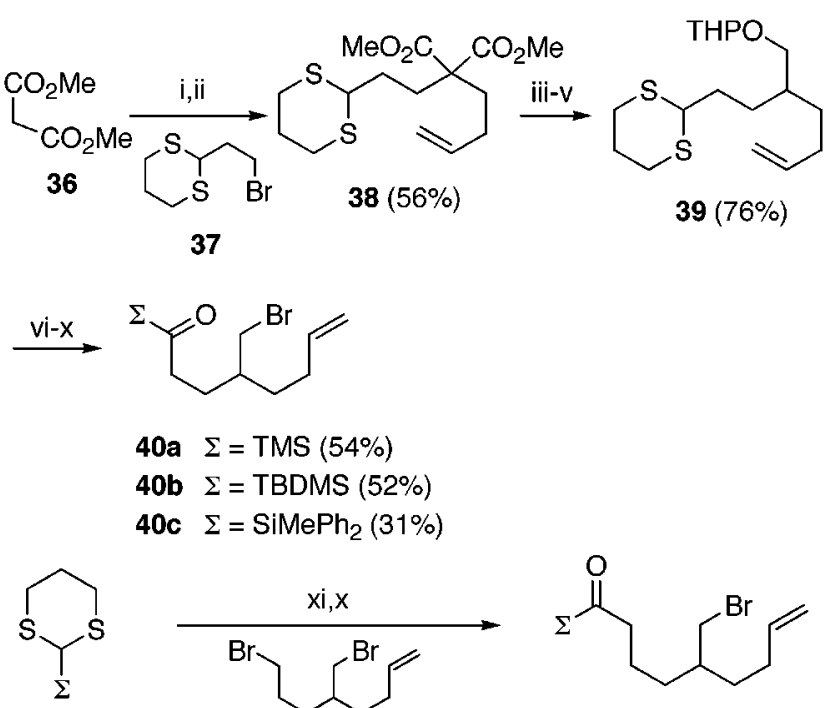

41a $\Sigma=$ TMS

41b $\Sigma=$ TBDMS
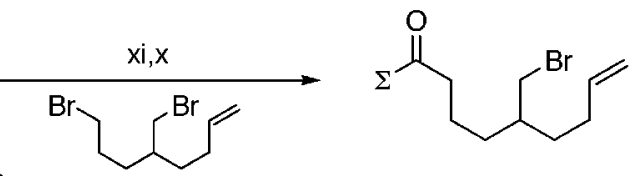

41c $\Sigma=\mathrm{SiMePh}_{2}$

42

41d $\Sigma=\mathrm{SiMe}_{2} \mathrm{Ph}$

41e $\Sigma=\mathrm{SiPh}_{3}$

$41 f \Sigma=\mathrm{SiMe}_{2}\left(4-\mathrm{MeOC}_{6} \mathrm{H}_{4}\right)$

41g $\Sigma=\mathrm{SiMe}_{2}\left(4-\mathrm{CF}_{3} \mathrm{C}_{6} \mathrm{H}_{4}\right)$

41h $\Sigma=\frac{1}{\mathrm{Me}^{\prime}} \mathrm{Si}=<\mathrm{OH}$

$41 \mathrm{i} \quad \Sigma=\frac{1}{\mathrm{Me}^{\prime}} \mathrm{Si} \underset{\mathrm{Ph}}{\mathrm{Ph}} \mathrm{Ph}$

41j $\Sigma=\frac{1}{\mathrm{Ph}^{\prime}} \mathrm{Si}-\mathrm{Ph}$<smiles>C=CCC(Br)CCCC(C)=O</smiles>

45

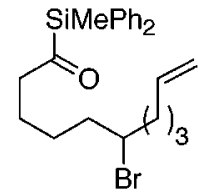

46

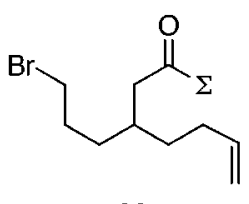

44

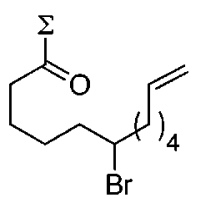

47 a Reagents and conditions: (i) $\mathrm{NaH}, \mathrm{DMF}$; 37; (ii) $\mathrm{NaH}, \mathrm{DMF}$; $\mathrm{BrCH}_{2} \mathrm{CH}_{2} \mathrm{CH}=\mathrm{CH}_{2}$; (iii) $\mathrm{NaCN}, \mathrm{DMF}, 150^{\circ} \mathrm{C}$; (iv) LAH, THF; (v) $\mathrm{TsOH}$, dihyropyran; (vi) BuLi, THF, $0{ }^{\circ} \mathrm{C} ; \Sigma-\mathrm{Cl}$; (vii) $\mathrm{TsOH}, \mathrm{MeOH}$; (viii) $\mathrm{MsCl}, \mathrm{Et}_{3} \mathrm{~N}, \mathrm{CH}_{2} \mathrm{Cl}_{2}$; (ix) $\mathrm{LiBr}$, acetone; (x) $\left(\mathrm{CF}_{3} \mathrm{CO}_{2}\right)_{2} \mathrm{IPh}$ for 40a; CAN, $\mathrm{H}_{2} \mathrm{O} / \mathrm{CH}_{3} \mathrm{CN},-20{ }^{\circ} \mathrm{C}$ for 40b, c, 43; (xi) BuLi, THF, 0 ${ }^{\circ} \mathrm{C} ; 42$.

33-35, respectively, have been reported. ${ }^{7,17-19}$ One should be able to use these known cyclization systems as intramolecular radical clocks to extrapolate the radical cyclization rate constants for acylsilanes.

As shown in Scheme 7, the 5-exo substrates primary bromides 40 were prepared from dimethyl malonate (36). Alkylation of $\mathbf{3 6}$ sequentially with 2-(2-bromoethyl)-1,3dithiane (37) 20 and 4-bromo-1-butene gave diester 38 in $56 \%$ yield. Decarbmethoxylation ${ }^{21}$ of diester 38 gave the corresponding monoester which was reduced to an al cohol

(17) Beckwith, A. L. J .; Easton, C. J .; Lawrence, T.; Serelis, A. K. Aust. J. Chem. 1983, 36, 545-556.

(18) Lusztyk, J .; Maillard, B.; Deycard, S.; Lindsay, D. A.; Ingold, K. U. J . Org. Chem. 1987, 52, 3509-3514.

(19) Beckwith, A. L. J .; Moad, G. J . Chem. Soc., Chem. Commun. 1974, 472-473.

(20) Davey, A. E.; Parsons, A. F.; Taylor, R. J . K. J . Chem. Soc., Perkin Trans. 1 1989, 1853-1858.

(21) McMurry, J. Org. React. 1976, 24, 187-224. and then converted to the tetrahydropyranyl ether 39 in $76 \%$ overall yield. Silylations of the 1,3-dithiane moiety in 39, followed by deprotection of the tetrahydropyranyl ethers, afforded the corresponding alcohols which were then converted to the bromides. The dithiane moiety was hydrolyzed with iodobenzenebis(trifluoroacetate) ${ }^{22}$ or $\mathrm{CAN}^{23}$ to afford acylsilanes $\mathbf{4 0 .}$

The 6-exo substrates primary bromides $\mathbf{4 3}$ were prepared by alkylations of 2-silyl-1,3-dithianes $\mathbf{4 1}$ with dibromide 42. Alkylations occurred selectively at the less hindered $\mathrm{C}(8)$ position of 42, and hydrolysis of the coupling products with CAN afforded acylsilanes 43. Only trace amounts of acylsilanes $\mathbf{4 4}$ were observed. These regioisomers were derived from alkylation of dithianes $\mathbf{4 1}$ with dibromide $\mathbf{4 2}$ at the C(5)-bromomethyl position. In contrast, when a similar strategy was carried out in the system of acylsilanes $\mathbf{4 0}$, the alkylations with 7-bromo5-(bromomethyl )-1-heptane gave a selectivity of 20:1 in favor of C(7)-alkylations. Because the regioi somers were difficult to separate, the dibromide alkylation approach to obtaining acylsilanes $\mathbf{4 0}$ was abandoned. The 5-exo substrates secondary bromides $\mathbf{4 5}$ and 6-exo substrates secondary bromides 46 and 47 were prepared according to the methods reported previously. ${ }^{14 b}$

The Rates of 5-Exo Cyclizations with Primary Radicals. The cyclizations of acylsilanes $\mathbf{4 0}$ were performed by slow addition ( $1 \mathrm{~h}$ ) of a benzene solution of tributyltin hydride (1.2 equiv) and AIBN (0.05 equiv) to a refluxing benzene solution of the acylsilane substrates. The results are summarized in Table 1 . In the case of acyltrimethylsilane $\mathbf{4 0 a}$ (entry 1 ), the carbonyl addition product silyl ether 48 a was obtained in $40 \%$ yield along with $23 \%$ of desilylated alcohol 49 . The desilylation of the labile trimethylsilyl group presumably occurred during silica-gel column chromatography. The ol efin addition product 50a was obtained in $24 \%$ yield. The ratio of the combined yields (63\%) of silyl ether 48a and alcohol 49 relative to the yield of acylsilane 50 a was determined to be 2.6. As mentioned above, this value should reflect the $\mathrm{k}_{\mathrm{C}=\mathrm{O}} / \mathrm{k}_{\mathrm{C}=\mathrm{C}}$ ratio. The olefin cyclization system in acylsilane 40 is reminiscent of the cyclization of 2-methyl-5-hexenyl radical 33 (Scheme 6). ${ }^{17}$ The difference between radical $\mathbf{3 3}$ and radicals derived from acylsilanes $\mathbf{4 0}$ is a methyl group versus a 2-(silylcarbonyl)ethyl group. Assuming the influence of this difference on $\mathrm{k}_{\text {cyclization }}$ is small, we used the rate constant $\mathrm{k}_{5}\left(3.3 \times 10^{6} \mathrm{~s}^{-1}\right.$ at $\left.80{ }^{\circ} \mathrm{C}\right)$ of the cyclization of radical 33 to extrapolate the $\mathrm{k}_{\mathrm{C}=0}$. Therefore, the 5-exo $\mathrm{k}_{\mathrm{C}=\mathrm{O}}$ for the primary radical derived from acyltrimethylsilane $\mathbf{4 0 a}$ was determined to be $8.6 \times 10^{6}$ $\mathrm{s}^{-1}$ at $80^{\circ} \mathrm{C}$.

When the silyl group was changed to a bulky tertbutyldimethylsilyl group in $\mathbf{4 0 b}$ (entry 2), the ratio of $\mathrm{k}_{\mathrm{C}=}$ $\mathrm{o} / \mathrm{k}_{\mathrm{C}=\mathrm{C}}$ decreased slightly to 1.5 . This correlates to a $\mathrm{k}_{\mathrm{C}=\mathrm{O}}$ value of $5.0 \times 10^{6} \mathrm{~s}^{-1}$ at $80^{\circ} \mathrm{C}$. This result indicates that for 5 -exo cyclization of acylsilanes with primary radicals the effect of the size of the silyl group is small. This is in sharp contrast to the 5-hexenyl radical cyclization system in which an alkyl substituent at $\mathrm{C}(5)$ severely reduces the 5-exo cyclization rate. ${ }^{7,11}$

Interestingly, acylmethyldiphenylsilane 40c (entry 3) cyclized very efficiently to give $78 \%$ of silyl ether $\mathbf{4 8 c}$

(22) Stork, G.; Zhao, K. Tetrahedron Lett. 1989, 30, 287-290.

(23) (a) Ho, T.-L.; Ho, H. C.; Wong, C. M. J. Chem. Soc., Chem. Commun. 1972, 791. (b) Ho, H. C.; Ho, T.-L.; Wong, C. M. Can. J . Chem. 1972, 50, 2718-2721. 
Table 1. The Radical Cyclizations of Acylsilanes $\mathbf{4 0}$ with Tributyltin Hydridea

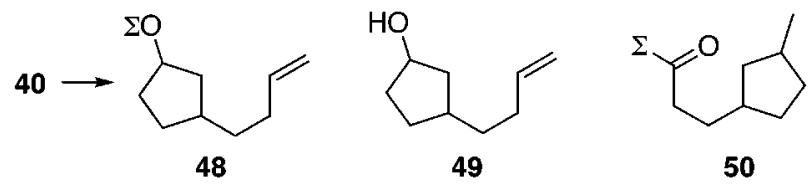

a $\Sigma=$ TMS; $\mathbf{b} \Sigma=$ TBDMS; $\mathbf{c} \Sigma=\mathrm{SiMePh}_{2}$

\begin{tabular}{|c|c|c|c|c|c|c|}
\hline entry & substrates & $\begin{array}{l}\text { silyl } \\
\text { groups }(\Sigma)\end{array}$ & $\begin{array}{c}\mathrm{C}=\mathrm{O} \text { addition products } \\
\left(^{\%} \text { yield; cis/trans }\right)^{\mathrm{b}}\end{array}$ & $\begin{array}{c}\mathrm{C}=\mathrm{C} \text { addition products } \\
(\% \text { yield; cis/trans) })^{\mathrm{b}}\end{array}$ & $\mathrm{k}_{\mathrm{C}=\mathrm{O}} / \mathrm{k}_{\mathrm{C}=\mathrm{C}^{\mathrm{C}}}$ & $\begin{array}{l}\text { extrapolated } \mathrm{k}_{\mathrm{C}=\mathrm{O} \times} \times \\
10^{-7}\left(\mathrm{~s}^{-1}\right) \text { at } 80^{\circ} \mathrm{C}^{\mathrm{d}}\end{array}$ \\
\hline $\begin{array}{l}1 \\
2 \\
3\end{array}$ & $\begin{array}{l}40 a \\
40 b \\
40 c\end{array}$ & $\begin{array}{l}\text { TMS } \\
\text { TBDMS } \\
\text { SiMePh }_{2}\end{array}$ & $\begin{array}{l}\text { 48a }(40 ; 55 / 45), 49(23)^{\mathrm{e}} \\
\mathbf{4 8 b}(49 ; 57 / 43) \\
\mathbf{4 8 c}(78 ; 53 / 47)\end{array}$ & $\begin{array}{l}\mathbf{5 0 a}(24 ; 1 / 2) \\
\mathbf{5 0 b}(33 ; 1 / 2) \\
\mathbf{5 0 c}(12 ; 1 / 2)\end{array}$ & $\begin{array}{l}2.6 \\
1.5 \\
6.5\end{array}$ & $\begin{array}{l}0.86 \\
0.50 \\
2.1\end{array}$ \\
\hline
\end{tabular}

${ }^{a} \mathrm{~A}$ benzene solution of tributyltin hydride (1.2 equiv) and AIBN (0.05 equiv) was added over $1 \mathrm{~h}$ to a refluxing benzene solution of the substrate. Equal amounts of benzene were used to prepare the two solutions, and the final concentration relative to the substrate was $0.05 \mathrm{M} .{ }^{\mathrm{b}}$ The cis/trans ratio was determined by ${ }^{1} \mathrm{H}$ NMR integration. ${ }^{\mathrm{C}}$ The ratio at $80{ }^{\circ} \mathrm{C}$. ${ }^{\mathrm{d}}$ The rate constants were based on a $\mathrm{k}_{\mathrm{C}}=\mathrm{C}$ value of $3.3 \times 10^{6} \mathrm{~s}^{-1}$ at $80^{\circ} \mathrm{C}$ ( $k_{5}$ in Scheme 6). I nherent error exists due to the selection of this value (see text). e The ratio of cis/trans isomers could not be determined.

along with $12 \%$ of acylsilane $50 \mathrm{c}$, and the ratio of $\mathrm{k}_{\mathrm{c}=\mathrm{O}} /$ $\mathrm{k}_{\mathrm{C}=\mathrm{C}}$ is 6.5. The $\mathrm{k}_{\mathrm{C}=\mathrm{O}}$ extrapolated from this ratio is 2.1 $\times 10^{7} \mathrm{~s}^{-1}$ at $80^{\circ} \mathrm{C}$. Although the methyldiphenyl group is presumably bulkier than the trimethylsilyl group, the cyclization rate constant is higher for acylmethyldiphenylsilane 40c than acyltrimethylsilane 40a. We assumed that this is a result of the electronic effect of the phenyl substituents on silicon (vide infra).

Beckwith and co-workers ${ }^{17}$ studied the radical cyclizations of methyl-substituted 5-hexenyl radicals. They found that the 5-exo cyclization rate constant of 2-methyl5-hexenyl radical $\mathbf{3 3}$ (Scheme 6) is greater than that of the parent 5-hexenyl radical $\mathbf{7 a}$ (Scheme 1 ) by a factor of 2.4 at $80{ }^{\circ} \mathrm{C}$. The acceleration effect of the 2-methyl group can be attributed to the gem-dialkyl effect. ${ }^{24}$ Taking this factor into account and on the basis of the results shown in Table 1, the rate constants of 5-exo cyclizations for unsubstituted acylsilanes with primary radicals should lie in the area of $10^{6} \mathrm{~s}^{-1}$ at $80^{\circ} \mathrm{C}$. This value is similar to the kinetics value for the analogous acylgermanes reported by Curran et al. (Scheme 2). ${ }^{9 c}$

The assignment of the stereochemical structures of $\mathbf{4 8}$ was based on the comparison of their ${ }^{1} \mathrm{H}$ NMR spectra with that of cis- and trans-3-methylcyclopentanol (51). ${ }^{25}$ A cis/trans (60/40) mixture of 3-methylcyclopentanol (51) was prepared from 3-methylcyclopentanone according to the literature. ${ }^{25}$ The ${ }^{1} \mathrm{H}$ NMR absorptions of $\mathrm{C}(1)-\mathrm{H}$ of cis-51 appeared at higher field between $\delta 4.13$ and 4.24, whereas that for the trans isomer appeared between $\delta$ 4.24 and 4.30 (entry 1, Table 2). As shown in Table 2, two sets of signals appeared in the same region for silyl ethers $48 \mathbf{a}-\mathbf{c}$. We assigned the set of signals that appeared at higher field to the cis isomers analogous to the trend observed in 3-methylcyclopentanol (51). Mechanistically, the stereochemistry of $\mathbf{4 8}$ is determined at the step of hydrogen abstraction of the rearranged $\alpha$-silyloxy radicals. Very little selectivity was observed in these 3-substituted cyclopentyl radicals. ${ }^{26}$

The stereochemistry of acylsilanes $\mathbf{5 0}$ was determined by comparison of their ${ }^{1} \mathrm{H}$ and ${ }^{13} \mathrm{C}$ NMR spectra with those of 1-tert-butyl-3-methylcyclopentane (52) reported by Beckwith ${ }^{27}$ (Table 3). The chemical shifts of the methyl

(24) (a) Beckwith, A. L. J .; Lawrence, T.J . Chem. Soc., Perkin Trans. 2 1979, 1535-1539. (b) Capon, B.; McManus, S. P. Neighboring Group Participation; Plenum Publishing: New York, 1976; Vol. 1, pp 58-75. (c) Kirby, A. J . Adv. Phys. Org. Chem. 1980, 17, 183-278.

(25) Battioni, J .-P.; Chodkiewicz, W. Bull. Soc. Chim. Fr. 1971 1824-1833.
Table 2. Comparison of the Characteristic ${ }^{1} \mathbf{H}$ NMR Absorptions of Silyl Ethers 48 with 3-Methylcyclopentanol (51)

\begin{tabular}{|c|c|c|c|}
\hline \multirow[b]{2}{*}{ entry } & \multirow[b]{2}{*}{ compounds } & \multicolumn{2}{|c|}{${ }^{1} \mathrm{H}$ NMR absorptions of $\mathrm{C}(1)-\mathrm{H}(\mathrm{ppm})^{\mathrm{a}}$} \\
\hline & & cis & $\operatorname{trans}^{b}$ \\
\hline 1 & 51 & $4.13-4.24^{b}$ & $4.24-4.30$ \\
\hline 2 & $48 a$ & $4.14^{c}$ & $4.19-4.28$ \\
\hline 3 & $48 b$ & $4.17 c$ & $4.20-4.30$ \\
\hline 4 & $48 c$ & $4.28^{c}$ & $4.32-4.42$ \\
\hline
\end{tabular}

a Deuterated chloroform was used as solvent. ${ }^{b}$ Appeared as a multiplet. ${ }^{\mathrm{C}} \mathrm{A}$ quintet with $\mathrm{J}=6 \mathrm{~Hz}$.

Table 3. Comparison of the Characteristic ${ }^{1} \mathrm{H}$ and ${ }^{13} \mathrm{C}$ NMR Absorptions of Acylsilanes 50 with 1-tert-Butyl-3-methylcyclopentane (52)

\begin{tabular}{|c|c|c|c|c|c|}
\hline \multirow[b]{2}{*}{ entry } & \multirow[b]{2}{*}{ compounds } & \multicolumn{2}{|c|}{$\begin{array}{l}{ }^{1} \mathrm{H} \text { NMR absorptions } \\
\text { of C(3)-Me (ppm) }{ }^{\mathrm{a}}\end{array}$} & \multicolumn{2}{|c|}{$\begin{array}{l}{ }^{13} \mathrm{C} \text { NMR absorptions } \\
\text { of C(3)-Me (ppm) }\end{array}$} \\
\hline & & cis & trans & cis & trans \\
\hline 1 & $52^{b}$ & 0.98 & 0.96 & 20.6 & 21.2 \\
\hline 2 & $50 a$ & 0.92 & 0.90 & 20.9 & 21.3 \\
\hline 3 & $50 b$ & 0.93 & 0.91 & 20.9 & 21.3 \\
\hline 4 & $50 c$ & 0.91 & 0.88 & 20.9 & 21.3 \\
\hline
\end{tabular}

a Deuterated chloroform was used as solvent. ${ }^{b}$ Ref 27.

substituent on cyclopentane for all the cis isomers appeared at lower field in ${ }^{1} \mathrm{H}$ NMR and higher field in ${ }^{13} \mathrm{C}$ NMR. These data indicate that the methyl group is located at a sterically more encumbered position. ${ }^{28}$ The observed 2/1 selectivity in favor of cis-50 follows the normal selectivity pattern for 5-exo cyclizations of 2-substituted 5-hexenyl radicals. 7,29

The Rates of 6-Exo Cyclizations with Primary Radicals. To probe the 6-exo cyclization rate constants of acylsilanes with primary radicals, we studied the cyclizations of acylsilanes 43. In 43, an intramolecular clock of a 2-substituted 5-hexenyl radical system was used again as in the case of acylsilanes $\mathbf{4 0}$. The results are shown in Table 4 . In the case of acyltrimethylsilane 43a (entry 1), desilylated cyclic alcohol cis-54 was isolated in $22 \%$ yield along with $3 \%$ of silyl ether trans-53a. The

(26) F or stereoselectivity of cycloalkyl radicals in general, see the following: Curran, D. P.; Porter, N. A.; Giese, B. Stereochemistry of Radical Reactions; VCH: New York, 1996; Chapter 3, p 116.

(27) Beckwith, A. L. J .; Zimmermann, J . J . Org. Chem. 1991, 56 5791-5796.

(28) Breitmaier, E.; Voelter, W. Carbon-13 NMR Spectroscopy, 3rd ed.; VCH: Weinhein, 1990; p 115

(29) Beckwith, A. L. J .; Lawrence, T.; Serelis, A. K. J . Chem. Soc., Chem. Commun. 1980, 484-485. 
Table 4. The Radical Cyclizations of Acylsilanes $\mathbf{4 3}$ with Tributyltin Hydride ${ }^{a}$
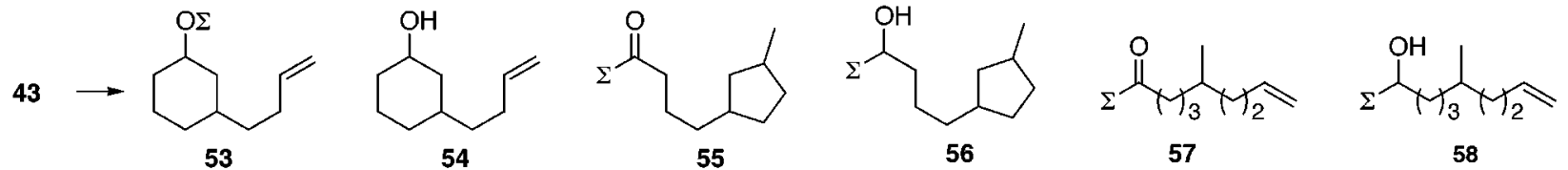

a $\Sigma=$ TMS; b $\Sigma=$ TBDMS; $\mathbf{c} \Sigma=\mathrm{SiMePh}_{2} ; \mathbf{d} \Sigma=\mathrm{SiMe}_{2} \mathrm{Ph} ;$ e $\Sigma=\mathrm{SiPh}_{3} ; \mathbf{f} \Sigma=\mathrm{SiMe}_{2}\left(4-\mathrm{MeOC}_{6} \mathrm{H}_{4}\right) ; \mathbf{g} \Sigma=$ $\mathrm{SiMe}_{2}\left(4-\mathrm{CF}_{3} \mathrm{C}_{6} \mathrm{H}_{4}\right)$

\begin{tabular}{|c|c|c|c|c|c|c|}
\hline entry & substrates & silyl groups $(\Sigma)$ & $\begin{array}{c}\mathrm{C}=\mathrm{O} \text { addition products } \\
(\% \text { yield })\end{array}$ & $\begin{array}{c}\mathrm{C}=\mathrm{C} \text { addition products } \\
\left(^{\%} \text { yield; cis/trans) }\right)^{\mathrm{b}}\end{array}$ & $\mathrm{k}_{\mathrm{C}=\mathrm{O}} / \mathrm{k}_{\mathrm{C}=\mathrm{C}^{\mathrm{C}}}$ & $\begin{array}{l}\text { extrapolated } \mathrm{k}_{\mathrm{C}=\mathrm{O} \times} \\
10^{-6}\left(\mathrm{~s}^{-1}\right) \text { at } 80^{\circ} \mathrm{C}^{\mathrm{d}}\end{array}$ \\
\hline 1 & 43a & TMS & trans-53a (3), cis-54 (22) & 55a $(59 ; 1 / 2)$ & 0.42 & 1.4 \\
\hline 2 & 43b & TBDMS & cis-53b (7) & $55 b(65)^{e}$ & 0.11 & 0.36 \\
\hline 3 & 43d & $\mathrm{SiMe}_{2} \mathrm{Ph}$ & trans-53d (6), cis-54 (21) & 55d $(55 ; 1 / 2), \mathbf{5 6 d}(4 ; 1 / 2.2)$ & 0.46 & 1.5 \\
\hline $4^{f}$ & 43c & $\mathrm{SiMePh}_{2}$ & cis-53c (19), trans-53c (5) & $55 c(46 ; 1 / 2.7)$ & 0.52 & 1.7 \\
\hline $5^{g}$ & $43 e$ & $\mathrm{SiPh}_{3}$ & cis-53e (16) & $55 \mathbf{e}(41 ; 1 / 2), 56 \mathbf{e}(13 ; 1 / 2.2)$ & 0.30 & 0.99 \\
\hline $6^{\mathrm{h}}$ & $43 f$ & $\mathrm{SiMe}_{2}\left(4-\mathrm{MeOC}_{6} \mathrm{H}_{4}\right)$ & $\begin{array}{l}\text { cis-53f (19), trans-53f (6), } \\
\text { cis-54 (3) }\end{array}$ & $55 f(59 ; 1 / 2)$ & 0.47 & 1.6 \\
\hline $7^{i}$ & $43 g$ & $\mathrm{SiMe}_{2}\left(4-\mathrm{CF}_{3} \mathrm{C}_{6} \mathrm{H}_{4}\right)$ & $\begin{array}{l}\text { cis-53g (16), trans-53g (8), } \\
\text { cis-54 (10) }\end{array}$ & $\mathbf{5 5} \mathbf{g}(44 ; 1 / 2), \mathbf{5 6 g}(2)^{\mathrm{e}}$ & 0.74 & 2.4 \\
\hline 8 & 43h & $-\mathrm{Si}=\angle \mathrm{OH}$ & cis-54 (34), trans-54 (9) & j & $0.89^{k}$ & 2.9 \\
\hline 9 & $43 i$ & $\stackrel{1}{\mathrm{Me}^{\prime}} \mathrm{Si}=\mathrm{Ph}$ & $\begin{array}{l}\text { cis-53i (25), trans-53i (10), } \\
\quad \text { cis-54 (13) }\end{array}$ & j & $1.0^{k}$ & 3.3 \\
\hline 10 & $43 j$ & $\mathrm{Ph}^{\prime} \mathrm{Si}=\mathrm{Ph}$ & $\begin{array}{l}\text { cis-53j (32), trans-53j (10), } \\
\quad \text { cis-54 (15) }\end{array}$ & j & $1.8^{\mathrm{k}}$ & 5.9 \\
\hline
\end{tabular}

a See footnote a in Table 1. ${ }^{b}$ The cis/trans ratio was determined by ${ }^{1} \mathrm{H}$ NMR integration. ${ }^{\mathrm{c}}$ The ratio at $80{ }^{\circ} \mathrm{C}$. ${ }^{\mathrm{d}}$ The rate constants were based on a $\mathrm{k}_{\mathrm{C}=\mathrm{C}}$ value of $3.3 \times 10^{6} \mathrm{~s}^{-1}$ at $80^{\circ} \mathrm{C}\left(\mathrm{k}_{5}\right.$ in Scheme 6). I nherent error exists due to the selection of this value (see text). e The isomeric ratio was not determined. ${ }^{f}$ Reduction product $\mathbf{5 7 c}$ was isolated in $6 \%$ yield. 9 Reduction product $\mathbf{5 8 e}$ was isolated in $5 \%$ yield. ${ }^{\mathrm{h}}$ Reduction product $\mathbf{5 7 f}$ was isolated in $6 \%$ yield. ${ }^{i}$ Reduction products $\mathbf{5 7 g}(5 \%)$ and $\mathbf{5 8 g}(\mathbf{2} \%)$ were also isolated. ${ }^{j}$ These addition products can be observed in the crude ${ }^{1} \mathrm{H}$ NMR spectrum, but we were unable to isolate them. ${ }^{k}$ The ratio was obtained by ${ }^{1} \mathrm{H}$ NMR integration of the crude product.

total yield of $25 \%$ represents the fraction of 6-exo cyclization at the acylsilane part. Olefin cyclization product acylsilane 55 a was obtained in $59 \%$ yield. The ratio of $\mathrm{C}=\mathrm{O}$ addition $\mathrm{C}=\mathrm{C}$ addition is 0.42 . This value should reflect the ratio of the rate constants of the two cyclizations. Using the 5-exo cyclization rate constant $k_{5}$ (Scheme 6) of 2-methyl-5-pentenyl radical to represent $k_{c=c}$, the $\mathrm{k}_{\mathrm{C}=\mathrm{O}}$ for acyltrimethylsilane 43a was extrapolated to be $1.4 \times 10^{6} \mathrm{~s}^{-1}$ at $80^{\circ} \mathrm{C}$. Comparing this value with the $\mathrm{k}_{\mathrm{C}=\mathrm{O}}$ for the corresponding 5-exo cyclization (entry 1 , Table 1) indicates that the 6-exo cyclization is slower by a factor of 6 in the case with a trimethylsilyl group.

Compared with the 5-exo cyclization, the 6-exo cyclization is al so more sensitive toward steric effects as shown in entry 2 . When the trimethylsilyl group was switched to a bulky tert-butyldimethylsilyl group, the amount of $\mathrm{C}=\mathrm{O}$ addition product decreased significantly. A small amount of silyl ether cis-53b (7\%) was isolated, and the major product was the acylsilane $55 \mathrm{~b}(65 \%)$. The $\mathrm{k}_{\mathrm{C}=0}$ in this case was extrapolated to be $3.6 \times 10^{5} \mathrm{~s}^{-1}$ at 80 ${ }^{\circ} \mathrm{C}$. A 4-fold drop from the case of acyltrimethylsilane $43 \mathrm{a}$ was observed.

In the case of one phenyl group on silicon as in acylsilane 43d (entry 3), silyl ether trans-53d (6\%) was obtained al ong with $21 \%$ of desilylated al cohol cis-54. The olefin cyclization products consisted of two compounds. The major compound was acylsilane $55 \mathbf{d}(55 \%)$, and a minor compound $\alpha$-silyl alcohol 56 (4\%) was also obtained. This $\alpha$-silyl alcohol was presumably derived from over-reduction of acylsilane $\mathbf{5 5} \mathbf{d}$ by tributyltin hydride..$^{30}$ Previously we have reported that the rate of reduction of an acylsilane moiety by tributyltin hydride is very close

(30) Ingold, K. U.; Lusztyk, J .; Scaiano, J. C. J. Am. Chem. Soc. 1984, 106, 343-348. to that of the reduction of a chloride. ${ }^{14 h}$ The reduction of chloride by tributyltin hydride is known to be much slower than the reduction of bromide. ${ }^{30-32}$ Therefore, it is unlikely that $\mathbf{5 6}$ was derived from, first, reduction of the carbonyl in acylsilane $\mathbf{4 3 d}$, followed by radical cyclization of the olefin. The $\mathrm{k}_{\mathrm{C}=\mathrm{O}}$ extrapolated from the cyclization of acylsilane $\mathbf{4 3 d}$ was determined to be $1.5 \times$ $10^{6} \mathrm{~s}^{-1}$ at $80{ }^{\circ} \mathrm{C}$.

With two phenyl groups on silicon as in acylsilane $\mathbf{4 3 c}$ (entry 4), the $\mathrm{k}_{\mathrm{C}=0}$ was determined to be $1.7 \times 10^{6} \mathrm{~s}^{-1}$ $\left(80^{\circ} \mathrm{C}\right)$. Although the size of the silyl group in acylmethyldiphenylsilane $\mathbf{4 3 c}$ is larger than that in acyldimethyl phenylsilane $\mathbf{4 3 d}$, the 6-exo cyclization rate constants of the two are similar. However, when the silyl group is very large as in acyltriphenylsilane $\mathbf{4 3 e}$ (entry 5 ), the $\mathrm{k}_{\mathrm{C}=}$ o $\left(9.9 \times 10^{5} \mathrm{~s}^{-1}\right.$ at $\left.80^{\circ} \mathrm{C}\right)$ becomes smaller than those of acylmethyldiphenylsilane 43c and acyldimethyl phenylsilane 43d. We believe that what we have observed in entries $3-5$ is the result of two counter acting factors. The steric factor slows down the rate of cyclization as the number of phenyl groups increases from entry 3 to 5. However, the acceleration effect of the phenyl group increases the cyclization rate as the number of phenyl groups increases.

The stereochemical assignments of silyl ethers $\mathbf{5 3}$ and desilylated alcohols $\mathbf{5 4}$ were based on the analysis of their ${ }^{1} \mathrm{H}$ NMR spectra. As shown in Table 5 , the $\mathrm{C}(1)-\mathrm{H}$ absorptions of the cis isomers all appeared at higher field as triplets of triplets with a large coupling constant of $\sim 10.5 \mathrm{~Hz}$ and a small coupling constant of $\sim 4.5 \mathrm{~Hz}$.
31) Carlsson, D. J .; Ingold, K. U. J . Am. Chem. Soc. 1968, 90, 7047-

(32) Beckwith, A. L. J .; Pigou, P. E. Aust. J . Chem. 1986, 39, 77- 
Table 5. ${ }^{1} \mathrm{H}$ NMR Absorptions of C(1)-H of Silyl Ethers 53 and Alcohols 54a

\begin{tabular}{cccc}
\hline entry & compounds & cis isomer $(\mathrm{ppm})^{\mathrm{b}}$ & $\begin{array}{c}\text { trans isomer } \\
(\mathrm{ppm})^{\mathrm{c}}\end{array}$ \\
\hline 1 & $\mathbf{5 3 a}$ & & 3.95 \\
2 & $\mathbf{5 3 b}$ & $3.50(\mathrm{~J}=10.3,4.2 \mathrm{~Hz})$ & \\
3 & $\mathbf{5 3 c}$ & $3.66(\mathrm{~J}=10.5,4.3 \mathrm{~Hz})$ & 4.12 \\
4 & $\mathbf{5 3 d}$ & & 4.30 \\
5 & $\mathbf{5 3 e}$ & $3.71(\mathrm{~J}=10.5,4.2 \mathrm{~Hz})$ & \\
6 & $\mathbf{5 4}$ & $3.53(\mathrm{~J}=10.7,4.5 \mathrm{~Hz})$ & 4.00
\end{tabular}

${ }^{a}$ Deuterated chloroform was used as solvent. ${ }^{b}$ Appeared as tt. c Appeared as a broad singlet.

These characteristic absorptions indicate that the hydrogens are located at the axial position. In contrast, the $\mathrm{C}(1)-\mathrm{H}$ absorptions of the trans isomers appeared at lower field as broad singlets, indicating that they are located at the equatorial position. Mechanistically, the stereochemistry was determined at the hydrogen-abstraction step of the $\alpha$-silyloxy radicals. It is well-known that cyclohexyl radicals prefer to abstract hydrogen from the axial site. ${ }^{26}$ Therefore, the cis isomers are expected to be the major isomers. The ster eochemistry of acylsilanes $\mathbf{5 5}$ agrees in all respects with that of acylsilanes $\mathbf{5 0 .}$

Probing the Electronics of the Silyl Group. To see if the electronic nature of the phenyl group on silicon will affect the cyclization or not, we studied the cyclization of acylsilanes $\mathbf{4 3 f}$ and $\mathbf{4 3 g}$ (entries 6 and 7, Table 4). In acylsilane 43f, an electron-donating methoxy group is present at the 4-position of the phenyl group. The ratio of $\mathrm{k}_{\mathrm{C}=0} / \mathrm{k}_{\mathrm{C}=\mathrm{C}}$ was determined to be 0.47 which is almost identical to that of the cyclization of acyldimethylphenylsilane 43d (entry 3). Therefore, an electron-rich phenyl group does not affect the rate of cyclization. However, when a trifluoromethyl group is present at the 4-position of the phenyl group as in acylsilane $\mathbf{4 3 g}$, the ratio of $\mathrm{k}_{\mathrm{C}=}$ $\mathrm{o} / \mathrm{k}_{\mathrm{C}=\mathrm{C}}$ increased 1.6-fold as compared with that of acyldimethylphenylsilane $\mathbf{4 3 d}$. This result indicates that the electron-withdrawing group on silicon will enhance the rate of cyclization. Presumably, as the silyl substituent becomes more electron withdrawing, the carbonyl carbon of the acylsilane will become more electropositive. The alkyl-substituted radicals involved in this work are nucleophilic and react faster with the more electrophilic carbonyls.

To further enhance the electrophilicity of the acylsilane carbonyl, we decided to attach an acetylenic group on silicon. The acetylenic group uses an sp orbital to bond with silicon and should be more electron withdrawing than the phenyl group which uses a less electronegative $\mathrm{sp}^{2}$ orbital for bonding. We prepared three acylsilanes $\mathbf{4 3 h} \mathbf{- j}$ that carry an acetylenic group using the method described above (Scheme 7). The cyclization results are shown in Table 4 (entries 8-10). As a result of the enhanced electrophilicity of the acylsilane carbonyls of this type, the olefin cyclization products, acylsilanes $\mathbf{5 5 h}-\mathbf{j}$, decomposed through extensive chromatography. Therefore, we determined the ratio of the carbonyl cyclization products to acylsilanes 55 by ${ }^{1} \mathrm{H}$ NMR integration of the cyclization crude product.

Interestingly, all the three acetylene-carrying acylsilanes $\mathbf{4 3 h}-\mathbf{j}$ underwent carbonyl cyclizations faster than all the other acylsilanes studied in this series (entries 1-7). Changing one methyl group on acyltrimethylsilane 43a (entry 1) to an acetylenic group as in acylsilane $\mathbf{4 3 h}$ (entry 8) doubled the carbonyl cyclization rate. Similarly, the same trend was observed when the cyclization results of acyldimethyl phenylsilane 43d (entry 3) and 43i (entry 9) were compared. When the methyl group in acylmethyldiphenylsilane 43c (entry 4) was changed to a phenylethynyl group as in acylsilane 43j (entry 10), the carbonyl cyclization rate increased 3.5 times. In the case of $\mathbf{4 3 j}$, the carbonyl cyclization products, silyl ethers 53j and alcohol 54, had a total yield of $57 \%$. This is the most efficient acylsilane cyclization in the 6-exo cyclization system. These results indicate that a directly attached acetylenic group on silicon increases the rate of acylsilane cyclization. In addition to the electronic effect of the acetylenic group, its smaller size may also play an important role in the acylsilane 6-exo cyclization system in which the cyclization is very sensitive toward the size of the silyl group. Therefore, while three phenyl groups on silicon as in acylsilane $\mathbf{4 3 e}$ (entry 5) is a slower carbonyl cyclization system, replacement of one phenyl group with a phenylethynyl group enhances the rate 6-fold.

In Curran's acylgermane system, ${ }^{9 \mathrm{C}}$ it was also reported that a electron-withdrawing substituent at the 4-position of the phenyl group on germanium increases the rate of radical cyclization. As shown in Scheme 2, for acylgermanes, the 6-exo cyclization rate constant $\mathrm{k}_{4}\left(1.3 \times 10^{6}\right.$ $\mathrm{s}^{-1}$ at $80{ }^{\circ} \mathrm{C}$ ) is also smaller than the 5 -exo cyclization rate constant $\mathrm{k}_{3}\left(6.4 \times 10^{6} \mathrm{~s}^{-1}\right.$ at $\left.80^{\circ} \mathrm{C}\right)$. Comparing the cyclization of acyltriphenylgermane $\mathbf{1 0}(n=2, R=P h)$ and acyltriphenylsilane 43e (entry 5, Table 4), the cyclization of $43 e$ is 6.5 times slower $\left(k_{\mathrm{C}=0}=9.9 \times 10^{5}\right.$ $\mathrm{s}^{-1}$ at $80^{\circ} \mathrm{C}$ ). Considering the gem-dialkyl effect ${ }^{24}$ exerted by the 4-pentenyl substituent at the $\beta$-position of the bromo group in acyltriphenylsilane 43e, the cyclization of the unsubstituted one should be even slower than acyltriphenylgermane $\mathbf{1 0}(\mathrm{n}=2, \mathrm{R}=\mathrm{Ph})$. However, changing one phenyl group on the silicon of acylsilane 43e to an acetylenic group, as in acylsilane 43j, can drive the acylsilane cyclization rate constant closer to that of acyltriphenylgermane $\mathbf{1 0}(n=2, R=P h)$.

The Rate of 5-Exo Cyclizations with Secondary Radicals. To probe the 5-exo radical cyclization of acylsilanes with secondary radicals, we studied the cyclizations of bromides $\mathbf{4 5 a}-\mathbf{d}$ (Table 6 ). In this system, the ol efin cyclization part involves a 1-substituted 5-hexenyl radical cyclization. Assuming that the difference between a silylcarbonyl propyl group and a methyl group is small, we used the $\mathrm{k}_{6}\left(7.0 \times 10^{5} \mathrm{~s}^{-1}\right.$ at $\left.80{ }^{\circ} \mathrm{C}\right)$ of 1-methyl-5-hexenyl radical cyclization involving 34, (Scheme 6) as our clock to probe the acylsilane cyclizations in bromides $\mathbf{4 5 a}-\mathbf{d}$.

The cyclization of acyltrimethylsilane $45 \mathrm{a}$ afforded silyl ether cis-59a (9\%) and cyclic alcohols cis-60 (9\%) and trans-60 (28\%). ${ }^{33}$ Alcohols 60 were derived from desilylation of silyl ethers 59a during column chromatography. In addition, the olefin cyclization products 61a were isolated in $46 \%$ yield as a mixture of cis/trans isomers. The yield of acylsilane 61a is the same as that of the combined carbonyl cyclization products. Therefore, the extrapolated $\mathrm{k}_{\mathrm{C}=\mathrm{O}}$ is $7.0 \times 10^{5} \mathrm{~s}^{-1}$ at $80^{\circ} \mathrm{C}$. This rateconstant value is about 1 order of magnitude lower than that of the corresponding 5-exo cyclization of a primary radical (entry 1, Table 1 ) and is one-half that of the corresponding 6-exo cyclization of a primary radical (entry 1, Table 4).

(33) (a) Shono, T.; Nishiguchi, I.; Ohmizu, H.; Mitani, M. J . Org. Chem. 1978, 100, 545-550. (b) Crandall, J . K.; Magaha, H. S. J . Org. Chem. 1982, 47, 5368-5371. 
Table 6. The Radical Cyclizations of Acylsilanes 45 with Tributyltin Hydride

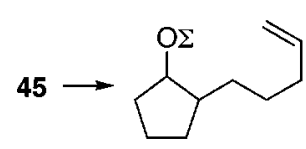

59

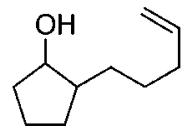

60

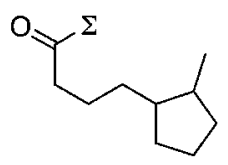

61

a $\Sigma=\mathrm{TMS} ;$ b $\Sigma=\mathrm{TBDMS} ; \mathbf{c} \Sigma=\mathrm{SiMePh}_{2} ;$ d $\Sigma=\mathrm{SiMe}_{2} \mathrm{Ph}$

\begin{tabular}{|c|c|c|c|c|c|c|}
\hline entry & substrates & $\begin{array}{l}\text { silyl } \\
\text { groups }(\Sigma)\end{array}$ & $\begin{array}{c}\mathrm{C}=\mathrm{O} \text { addition products } \\
(\% \text { yield })\end{array}$ & $\begin{array}{c}\mathrm{C}=\mathrm{C} \text { addition products } \\
(\% \text { yield; cis/trans })^{\mathrm{b}}\end{array}$ & $\mathrm{k}_{\mathrm{C}=\mathrm{O}} / \mathrm{k}_{\mathrm{C}=\mathrm{C}^{\mathrm{C}}}$ & $\begin{array}{l}\text { extrapolated } \mathrm{k}_{\mathrm{C}=\mathrm{O}} \times \\
10^{-6}\left(\mathrm{~s}^{-1}\right) \text { at } 80^{\circ} \mathrm{C}^{\mathrm{d}}\end{array}$ \\
\hline 1 & $45 a$ & TMS & cis-59a (9), cis-60 (9), trans-60 (28) & 61a $(46 ; 2 / 1)$ & 1.0 & 0.70 \\
\hline 2 & 45b & TBDMS & cis-59b (19), trans-59b (17) & $\mathbf{6 1 b}(36 ; 2 / 1)$ & 1.0 & 0.70 \\
\hline 3 & 45c & $\mathrm{SiMePh}_{2}$ & cis-59c (36), trans-59c (36) & $61 c(26 ; 2.3 / 1)$ & 2.8 & 2.0 \\
\hline 4 & 45d & $\mathrm{SiMe}_{2} \mathrm{Ph}$ & cis-59d (30), trans-59d (37) & 61d $(29 ; 2 / 1)$ & 2.3 & 1.6 \\
\hline
\end{tabular}

a See footnote a in Table 1. ${ }^{b}$ The cis/trans ratio was determined by ${ }^{1} \mathrm{H}$ NMR integration. ${ }^{c}$ The ratio at $80{ }^{\circ} \mathrm{C}$. ${ }^{d}$ The rate constants were based on a $\mathrm{k}_{\mathrm{C}=\mathrm{C}}$ value of $7.0 \times 10^{5} \mathrm{~s}^{-1}$ at $80^{\circ} \mathrm{C}$ ( $\mathrm{k}_{6}$ in Scheme 6). Inherent error exists due to the selection of this value (see text).

Table 7. Comparison of the Characteristic NMR Absorptions of Silyl Ethers 59 with 2-Methylcyclopentyl Methyldiphenylsilyl Ether (62) ${ }^{\mathrm{a}}$

\begin{tabular}{|c|c|c|c|c|c|}
\hline \multirow[b]{2}{*}{ entry } & \multirow[b]{2}{*}{ compounds } & \multicolumn{2}{|c|}{$\begin{array}{c}{ }^{1} \mathrm{H} \text { NMR absorptions } \\
\text { of OCH (ppm) }\end{array}$} & \multicolumn{2}{|c|}{$\begin{array}{c}{ }^{13} \mathrm{C} \text { NMR absorptions } \\
\text { of } \mathrm{OCH}(\mathrm{ppm})\end{array}$} \\
\hline & & $c i s^{b}$ & $\operatorname{trans}^{\mathrm{c}}$ & cis & trans \\
\hline 1 & $62^{d}$ & 4.16 & 3.77 & e & 81.3 \\
\hline 2 & $60^{f}$ & 4.1 & 3.79 & & \\
\hline 3 & $59 b$ & 4.05 & 3.67 & 75.0 & 79.6 \\
\hline 4 & $59 c$ & 4.23 & 3.85 & 76.0 & 80.1 \\
\hline 5 & 59d & 4.11 & 3.70 & 75.5 & 79.7 \\
\hline
\end{tabular}

a Deuterated chloroform was used as the solvent. ${ }^{b}$ Appeared as a broad singlet. ' $A$ ppeared as a quartet. ${ }^{\mathrm{d}}$ Reference $14 \mathrm{~h}$. e Overlapped with signals of $\mathrm{CDCl}_{3} .{ }^{\mathrm{f}}$ Reference 33.

Changing the silyl group to a bulkier tert-butyldimethylsilyl group as in acylsilane 45b (entry 2) did not change the ratio of $\mathrm{k}_{\mathrm{C}=\mathrm{O}} / \mathrm{k}_{\mathrm{C}=\mathrm{C}}$. These results indicated that this system is not sensitive toward the steric size of the silyl group. With the presence of phenyl groups on silicon as in acylmethyldi phenylsilane 45c (entry 3), the carbonyl cyclization rate constant is almost tripled as compared with that of acyltrimethylsilane $4 \mathbf{4 5 a}$. The rate constant of carbonyl cyclization for acyldimethylphenylsilane 45d (entry 4) is also doubled as compared with acyltrimethylsilane $\mathbf{4 5 a}$.

The stereochemistry of silyl ethers $\mathbf{5 9}$ and alcohols 60 was deduced by comparison of their NMR data with that of 2-methylcyclopentyl methyldiphenylsilyl ether (62). ${ }^{14 h}$ As shown in Table 7, the ${ }^{1} \mathrm{H}$ NMR absorption of the $\mathrm{C}(1)-\mathrm{H}$ of all the cis-isomers appeared at lower field and that of the trans-isomers appeared at higher field. In their ${ }^{13} \mathrm{C}$ NMR spectra, the chemical shifts of $\mathrm{C}(1)$ of the cis isomers appeared at higher field and that of the trans isomers appeared at lower field. Trimethylsilyl ether cis-59a was desilylated (TBAF/THF) to give alcohol cis-60 and thus secured the stereochemistry of cis-59a. As mentioned before, the stereochemical results were determined at the stage of hydrogen abstraction of the cyclized cyclic $\alpha$-silyloxy radical. In the cases of the cyclizations of acylsilanes 45, almost equal amounts of cis/trans isomers of silyl ethers $\mathbf{5 9}$ were obtained. These results indicate that no facial selectivity exists for this type of 2-substituted cyclopentyl radical. ${ }^{26}$

The ${ }^{13} \mathrm{C}$ NMR absorptions of the methyl group on the cyclopentane ring of acylsilanes cis-61 all appeared at higher field at $\delta$ 14.7, indicating that the methyl groups are located at a sterically more encumbered position. In contrast, the methyl group absorptions of the corresponding trans isomers appeared at lower field of $\delta$ 19.4. The cis sel ectivity observed in the formation of acylsilanes $\mathbf{6 1}$ is well-known for the cyclizations of 1-substituted 5-hexenyl radicals. ${ }^{7,26,29}$

In general, the $\mathrm{k}_{\mathrm{C}=\mathrm{O}}$ values for 5-exo cyclizations of acylsilanes involving secondary radicals fall in the vicinity of $1.0 \times 10^{6} \mathrm{~s}^{-1}$ at $80^{\circ} \mathrm{C}$. These values are similar to those of the acylsilane cyclizations involving 6-exo mode and primary radicals. In the acylgermane system, the cyclization of (5-bromohexanoyl)triphenylgermane was estimated to have a rate constant of about $5 \times 10^{6} \mathrm{~s}^{-1}$ at $80{ }^{\circ} \mathrm{C}$. $9 \mathrm{c}$ To compare with this acylgermane, the closest analogy that we have is the acylmethyldiphenylsilane $45 \mathrm{c}\left(\mathrm{k}_{\mathrm{C}=\mathrm{O}}=2.0 \times 10^{6} \mathrm{~s}^{-1}\right.$ at $\left.80^{\circ} \mathrm{C}\right)$. The acylsilane system appears to be slower in this category.

The Rate of 6-Exo Cyclizations with Secondary Radicals. To probe the 6-exo cyclizations of acylsilanes with secondary radicals, we studied the cyclization of acylmethyldiphenylsilane 46 (eq 2). From our previous

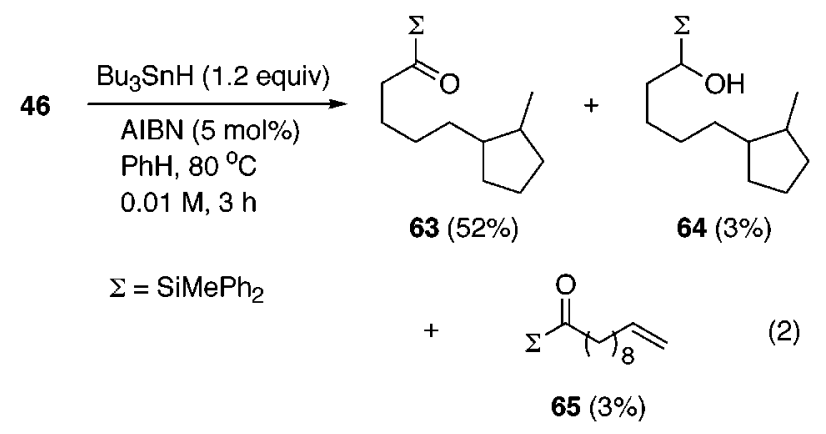

research, ${ }^{14 \mathrm{~h}}$ we knew that secondary radicals undergo slow 6-exo cyclizations with acylsilanes. The concentration has to be very dilute to obtain a significant amount of cyclization products. Therefore, we used a concentration of $0.01 \mathrm{M}$ for the study of the cyclization of acylsilane 46. A 1-substituted 5-hexenyl radical cyclization was used as an intramolecular clock. The cyclization reaction afforded $52 \%$ yield of cyclized acylsilane 62 and $\alpha$-silyl alcohol 64 (3\%). A small amount of uncyclized reduction product 65 (3\%) was also isolated. There was no product derived from carbonyl cyclization. This result indicated that in acylsilane $\mathbf{4 6}$ the intramolecular clock is too fast to probe the acylsilane cyclization.

We next turned to the cyclization of acylsilanes 47 . In 47, a 1-substituted 6-heptenyl radical cyclization was 
Table 8. The Radical Cyclizations of Acylsilanes 47 with Tributyltin Hydridea<smiles>C=CC1CCCCC1[O]</smiles>

66<smiles>CC(=O)NC1CCCCC1C</smiles>

67<smiles>CC(O)CC1CCCCC1C</smiles>

68<smiles>C=CC(C)=O</smiles>

69

a $\Sigma=$ TMS; $\mathbf{b} \Sigma=$ TBDMS; $\mathbf{c} \Sigma=\mathrm{SiMePh}_{2}$

\begin{tabular}{|c|c|c|c|c|c|c|}
\hline entry & substrates & $\begin{array}{l}\text { silyl } \\
\text { groups }(\Sigma)\end{array}$ & $\begin{array}{c}\mathrm{C}=\mathrm{O} \text { addition products } \\
(\% \text { yield; cis/trans })^{\mathrm{b}}\end{array}$ & $\begin{array}{c}\mathrm{C}=\mathrm{C} \text { addition products } \\
\left(^{\%} \text { yield; cis/trans }\right)^{\mathrm{b}}\end{array}$ & $\mathrm{k}_{\mathrm{C}=\mathrm{O}} / \mathrm{k}_{\mathrm{C}=\mathrm{C}^{\mathrm{C}}}$ & $\begin{array}{l}\text { extrapolated } \mathrm{k}_{\mathrm{C}}=\mathrm{O} \times \\
10^{-5}\left(\mathrm{~s}^{-1}\right) \text { at } 80^{\circ} \mathrm{C}^{\mathrm{d}}\end{array}$ \\
\hline $1^{e, f}$ & $47 a$ & TMS & $\mathbf{6 6 a}(12 ; 1 / 2.7)$ & 67a $(14 ; 1 / 1)$ & 0.86 & 0.35 \\
\hline $\begin{array}{l}2^{e, 9} \\
3^{h}\end{array}$ & $\begin{array}{l}47 b \\
47 c\end{array}$ & $\begin{array}{l}\text { TBDMS } \\
\text { SiMePh }_{2}\end{array}$ & $66 c(17 ; 1 / 2)$ & $\begin{array}{l}\mathbf{6 7 b}(18 ; 1 / 1) \\
\mathbf{6 8 c}(6)\end{array}$ & 2.8 & 1.1 \\
\hline
\end{tabular}

a See footnote a in Table 1. The final concentration relative to 47 was $0.01 \mathrm{M}$. ${ }^{\mathrm{b}}$ The cis/trans ratio was determined by ${ }^{1} \mathrm{H}$ NMR integration. ${ }^{c}$ The ratio at $80^{\circ} \mathrm{C}$. d The rate constants were based on a $\mathrm{k}_{\mathrm{C}=\mathrm{C}}$ value of $4.1 \times 10^{4} \mathrm{~s}^{-1}$ at $80^{\circ} \mathrm{C}$ ( $\mathrm{k}_{7}$ in Scheme 6). Inherent error exists due to the selection of this value (see text). ${ }^{e}$ The yields were obtained by a combination of isolation and ${ }^{1} \mathrm{H} N M \mathrm{R}$ integration. ${ }^{\mathrm{f}}$ Reduction product 69 a was also present in $59 \%$ yield. ${ }^{g}$ Reduction product $69 \mathrm{~b}$ was also present in $69 \%$ yield. ${ }^{\mathrm{h}}$ Reduction product $69 \mathrm{c}$ was isolated in $65 \%$ yield.

used as the intramol ecular clock. Unfortunately, the cydization rate constant of 1-substituted 6-heptenyl radical has not been determined in the literature. However, the 6-exo cyclization rate constant $\left(k_{7}\right.$, Scheme 6$)$ of 6-heptenyl radical (35) has been reported by Beckwith ${ }^{7,19}$ to be $4.1 \times 10^{4} \mathrm{~s}^{-1}\left(80^{\circ} \mathrm{C}\right)$. This value was used to approximate the rate constant of the 6-heptenyl radical cyclization system present in acylsilane 47. In the case of 5hexenyl radical ( $7 a, n=1$; Scheme 1$)$, a methyl substituent at $C(1)$ as in radical $\mathbf{3 4}$ (Scheme 6) decreases the $\mathrm{k}_{5-\text { exo }}$ value at $80^{\circ} \mathrm{C}$ by one-half. Therefore, the use of $\mathrm{k}_{7}$ to approximate the 6-exo cyclization rate constant of 1-substituted 1-heptenyl radical is likely overestimated.

As shown in Table 8, the cyclization of acyltrimethylsilane 47a (entry 1) gave a mixture of carbonyl addition product $66 \mathbf{a}(12 \%)$, ol efin addition product 67 a (14\%), and uncyclized reduction product 69 a (59\%). Due to the difficulty of separation, the yields of cyclization products were calculated on the basis of ${ }^{1} \mathrm{H}$ NMR integration of the mixture. The $\mathrm{k}_{\mathrm{C}=\mathrm{O}}$ extrapolated from this result had a value of $3.5 \times 10^{4} \mathrm{~s}^{-1}\left(80^{\circ} \mathrm{C}\right)$. As mentioned above, the actual value may be lower. This rate constant is at least 40 times slower than that of the corresponding 6-exo cyclization of a primary radical (entry 1 , Table 4).

With a bulky TBDMS group as in acylsilane 47b (entry 2 ), we were able to obtain a mixture of the ol efin addition product $67 \mathbf{b}$ (18\%) and the uncyclized reduction product 69b (69\%). The carbonyl addition product was not observed. This result indicated that the acylsilane cyclization in acylsilane $\mathbf{4 7 b}$ is much slower than that in acyltrimethylsilane 47a.

In the case of acylmethyldiphenylsilane 47c (entry 3), the cyclization gave $65 \%$ of uncyclized acylsilane $69 \mathrm{c}$ along with a mixture of cyclized ether $\mathbf{6 6 c}(17 \%)$ and $\alpha$-silyl alcohol 68c (6\%). The $\mathrm{k}_{\mathrm{c}=\mathrm{O}}$ obtained from this study gave what is presumably an overestimated value of $1.1 \times 10^{5} \mathrm{~s}^{-1}\left(80^{\circ} \mathrm{C}\right)$. This rate constant is about three times that of the acyltrimethylsilane $\mathbf{4 7 a}$.

In general, the 6-exo cyclizations of acylsilanes involving secondary radicals are at least an order of magnitude slower than the corresponding cyclizations of primary radicals. The 1,6-cyclization of a secondary radical with acyltriphenylgermane ${ }^{9 d}$ was estimated to have a $k_{\text {cyclization }}$ in the range of $(5-6) \times 10^{5} \mathrm{~s}^{-1}$. Therefore, again, the acyltriphenylgermane system cyclizes more efficiently than the acylsilane system.

The stereochemical assignment of the cyclized silyl ethers 66 was based on the spectroscopic data of 2- methylcyclohexyl silyl ethers reported previously. ${ }^{14 \mathrm{~h}}$ In acylsilanes $\mathbf{6 7 a}$ and $\mathbf{6 7} \mathbf{b}$, two methyl doublets of equal intensity appeared at $\delta 0.78$ and 0.84 which correl ate well with those of the cis- and trans-1,2-dimethylcyclohexane ${ }^{34}$ (methyl doublets at $\delta 0.83$ for the cis isomer and 0.90 for the trans isomer). The characteristic absorptions of $\alpha$-silyl alcohol 68c contained four sets of overlapped doublets, and the isomeric ratio was not determined.

\section{Conclusions}

In this study, using the intramolecular competition experiments we were able to determine the approximate rates of radical cyclizations of acylsilanes. In general, for acylsilanes, the 5-exo cyclization rate constants involving primary radicals determined at $80^{\circ} \mathrm{C}$ are approximately $10^{6} \mathrm{~s}^{-1}$. The rate constants for 6-exo cyclizations of primary radicals and the 5-exo cyclizations of secondary radicals are approximately $10^{5} \mathrm{~s}^{-1}$. The 6-exo cyclizations with secondary radicals are the slowest, and the cyclization rate constants are approximately $10^{4} \mathrm{~s}^{-1}$. The values of the cyclization rate constants are dependent upon the substituents on silicon. The 6-exo cyclizations are sensitive toward steric effect; therefore, a bulky silyl group reduces the cyclization rate significantly. The presence of a phenyl group on silicon increases the rate, and this effect is probably the result of the electron-withdrawing nature of the phenyl group. The acetylenic group on silicon also accelerates the cyclization, and this phenomenon is probably due to the smaller size and el ectronwithdrawing nature of the acetylenic group. Due to the ease of preparation, we suggest using the methyldiphenylsilyl group in synthetic applications of acylsilane cyclizations.

With limited kinetic data on $\omega$-formyl radical cyclizations $^{6}$ available for comparison, the acylsilane radical cyclizations appear to be equally fast when the right silyl group is chosen. The acylsilane system is therefore a good synthetic equival ent of the $\omega$-formyl radical cyclizations. The advantage of the acylsilane system is the irreversible nature of the cyclization. Compared with acylgermanes, ${ }^{9}$ the acylgermane radical cyclizations appear to be less sensitive to the steric size of the germyl group. This may be attributed to the longer $\mathrm{C}-\mathrm{Ge}$ bond. A similar electronic effect on cyclizations was also reported in the

(34) Pouchert, C. J . TheAldrich Library of NMR Spectrum; 2nd ed.; Aldrich Chemical: Milwaukee, 1983; 1(1), 51A, 51B. 
case of acylgermanes. The radical cyclization rates of acylgermanes are also dependent on the nature of the initial radical. Although the radical cydizations of acylgermanes and acylsilanes are similar in many ways, the two systems yield different types of end products. The acylgermanes lead to the formation of cyclic ketones, while the acylsilanes afford silyl-protected cyclic al cohols. The two systems are complementary.

\section{Experimental Section}

Melting points are uncorrected. ${ }^{1} \mathrm{H}$ NMR spectra were recorded at 200 or $300 \mathrm{MHz} ;{ }^{13} \mathrm{C} \mathrm{NMR}$ spectra were recorded at 50 or $75 \mathrm{MHz}$. Tetramethysilane $(\delta=0 \mathrm{ppm})$ or $\mathrm{CHCl}_{3}(\delta$ $=7.24 \mathrm{ppm}$ ) were used as internal standards, and $\mathrm{CDCl}_{3}$ was used as the solvent. Benzene and THF were distilled from sodium benzophenone ketyl under $\mathrm{N}_{2}$. Dimethylformamide (DMF) was dried over calcium hydride. Acetone was distilled over sodium carbonate. The benzene used for cyclization reactions was deoxygenated by passing a gentle stream of argon through for $0.5 \mathrm{~h}$ before use. All reactions were performed under a blanket of $\mathrm{N}_{2}$ or $\mathrm{Ar}$.

Dimethyl 2-(3-Butenyl)-2-(2-(2,6-dithiacyclohexyl)ethyl)malonate (38). To a mixture of $204 \mathrm{mg}(6.8 \mathrm{mmol})$ of sodium hydride ( $80 \%$ dispersion in mineral oil) in $6 \mathrm{~mL}$ of DMF cooled at $0{ }^{\circ} \mathrm{C}$ was added dropwise over $10 \mathrm{~min}$ a solution of $0.71 \mathrm{~mL}(6.2 \mathrm{mmol})$ of dimethyl malonate in $3 \mathrm{~mL}$ of DMF. The resulting mixture was stirred at the same temperature for $10 \mathrm{~min}$ followed by the addition of a solution of $1.41 \mathrm{~g}(6.2$ $\mathrm{mmol}$ ) of bromide $\mathbf{3 7}$ in $3 \mathrm{~mL}$ of DMF in one portion. The reaction mixture was stirred at $80{ }^{\circ} \mathrm{C}$ for $3 \mathrm{~h}$ and then partitioned between $100 \mathrm{~mL}$ of ether and $100 \mathrm{~mL}$ of water. The ether phase was washed with brine $(100 \mathrm{~mL})$, dried $\left(\mathrm{MgSO}_{4}\right)$, and concentrated in vacuo. The resulting residual oil was dissolved in $3 \mathrm{~mL}$ of DMF and then added dropwise over $10 \mathrm{~min}$ to another mixture of $204 \mathrm{mg}(6.8 \mathrm{mmol})$ of sodium hydride ( $80 \%$ dispersion in mineral oil) in $6 \mathrm{~mL}$ of DMF at 0 ${ }^{\circ} \mathrm{C}$. The resulting mixture was stirred at room temperature for $10 \mathrm{~min}$ following which was added a solution of $0.66 \mathrm{~mL}$ $(6.5 \mathrm{mmol})$ of 4-bromo-1-butene in $3 \mathrm{~mL}$ of DMF in one portion. The reaction mixture was stirred at $60{ }^{\circ} \mathrm{C}$ for $2 \mathrm{~h}$ and then partitioned between $100 \mathrm{~mL}$ of ether and $100 \mathrm{~mL}$ of water. The ether phase was washed with brine $(100 \mathrm{~mL})$, dried $\left(\mathrm{MgSO}_{4}\right)$, and concentrated in vacuo. The residual oil was chromatographed over silica gel (eluted with hexane/ethyl acetate, 89/11) to give $1.14 \mathrm{~g}(56 \%)$ of $\mathbf{3 8}$ as a pale yellow liquid: IR (neat) 1727, $1633 \mathrm{~cm}^{-1}$; ${ }^{1} \mathrm{H}$ NMR $(200 \mathrm{MHz}) \delta 1.55-$ $1.70(\mathrm{~m}, 2 \mathrm{H}), 1.70-2.00(\mathrm{~m}, 5 \mathrm{H}), 2.00-2.18(\mathrm{~m}, 3 \mathrm{H}), 2.71-$ $2.95(\mathrm{~m}, 4 \mathrm{H}), 3.68(\mathrm{~s}, 6 \mathrm{H}), 3.94(\mathrm{t}, \mathrm{J}=6.9 \mathrm{~Hz}, 1 \mathrm{H}), 4.92(\mathrm{br}$ $\left.d_{,} J=10.7 \mathrm{~Hz}, 1 \mathrm{H}\right), 4.99(\mathrm{br} d, J=16.6 \mathrm{~Hz}, 1 \mathrm{H}), 5.60-5.85$ $(\mathrm{m}, 1 \mathrm{H}) ;{ }^{13} \mathrm{C} N M R(50 \mathrm{MHz}) \delta 25.7(\mathrm{t}), 28.2(\mathrm{t}), 29.6(\mathrm{t}), 30.0$ (t), $31.6(\mathrm{t}), 47.0$ (d), $52.2(\mathrm{q}), 56.7(\mathrm{~s}), 115.0(\mathrm{t}), 137.0(\mathrm{~d}), 171.3$ (s); HRMS calcd for $\mathrm{C}_{15} \mathrm{H}_{24} \mathrm{O}_{4} \mathrm{~S}_{2} \mathrm{~m} / \mathrm{z} 332.1116$, found 332.1115.

2-(3-(Tetrahydropyranyloxymethyl)hept-6-enyl)-1,3dithiane (39). To a mixture of $731 \mathrm{mg}(14.9 \mathrm{mmol})$ of sodium cyanide in $4 \mathrm{~mL}$ of DMF was added in one portion a solution of $2.92 \mathrm{~g}(8.8 \mathrm{mmol})$ of malonate 38 in $5 \mathrm{~mL}$ of DMF. The resulting mixture was heated at $164{ }^{\circ} \mathrm{C}$ for $3 \mathrm{~h}$ and then partitioned between $100 \mathrm{~mL}$ of ether and $100 \mathrm{~mL}$ of water. The aqueous phase was extracted with ether $(100 \mathrm{~mL})$. The combined ether layers were washed with brine $(50 \mathrm{~mL})$, dried $\left(\mathrm{MgSO}_{4}\right)$, and concentrated in vacuo. The resulting brown liquid was dissolved in $8 \mathrm{~mL}$ of THF and then added dropwise over $10 \mathrm{~min}$ to a mixture of $500 \mathrm{mg}$ (13.2 mmol) of LAH in 8 $\mathrm{mL}$ of $\mathrm{THF}$ at $0{ }^{\circ} \mathrm{C}$. The reaction mixture was stirred at room temperature for $1.5 \mathrm{~h}$ and then diluted with $10 \mathrm{~mL}$ of ether. To the resulting mixture cooled at $0{ }^{\circ} \mathrm{C}$ was added in sequence $0.5 \mathrm{~mL}$ of water, $0.5 \mathrm{~mL}$ of $15 \%$ sodium hydroxide solution, and $1.5 \mathrm{~mL}$ of water. The reaction mixture was then stirred at room temperature for $30 \mathrm{~min}$, filtered, and concentrated in vacuo. To the residual oil was added a few crystals of p-toluenesulfonic acid monohydrate and $0.963 \mathrm{~mL}(10.6 \mathrm{mmol})$ of dihydropyran, and the resulting mixture was stirred at room temperature for $3 \mathrm{~h}$. To the resulting liquid was added one drop of triethylamine, and the resulting mixture was chromatographed over silica gel (eluted with hexane/ethyl acetate, 9/1) to give $2.2 \mathrm{~g}(76 \%)$ of 39 as a colorless liquid. This material is a mixture of two diastereomers: IR (neat) $1632 \mathrm{~cm}^{-1} ;{ }^{1} \mathrm{H}$ NMR $(200 \mathrm{MHz}) \delta 1.20-1.93(\mathrm{~m}, 15 \mathrm{H}), 2.00-2.18(\mathrm{~m}, 2 \mathrm{H})$, 2.70-2.94 (m, 4 H), 3.21 (ddd, J = 10.6, 5.8, 4.9 Hz, 1 H), 3.47 $(\mathrm{dt}, \mathrm{J}=11.3,4.5 \mathrm{~Hz}, 1 \mathrm{H}$ ), 3.63 (ddd, J $=10.6,5.3,3.7 \mathrm{~Hz}, 1$ H), 3.81 (ddd, J = 11.3, 6.9, $3.2 \mathrm{~Hz}, 1 \mathrm{H}$ ), $4.00(\mathrm{t}, \mathrm{J}=6.5 \mathrm{~Hz}$, $1 \mathrm{H}), 4.53(\mathrm{t}, \mathrm{J}=3.2 \mathrm{~Hz}, 1 \mathrm{H}), 4.91(\mathrm{br} d, \mathrm{~J}=10.3 \mathrm{~Hz}, 1 \mathrm{H})$, $4.98(\mathrm{br} \mathrm{d}, \mathrm{J}=16.9 \mathrm{~Hz}, 1 \mathrm{H}), 5.77$ (ddt, J $=16.9,10.3,6.6 \mathrm{~Hz}$, $1 \mathrm{H}) ;{ }^{13} \mathrm{C}$ NMR (50 MHz) $\delta 19.4(\mathrm{t}), 25.5(\mathrm{t}), 26.0(\mathrm{t}), 28.5(\mathrm{t})$, $30.4(\mathrm{t}), 30.6(\mathrm{t}), 31.0(\mathrm{t}), 32.9(\mathrm{t}), 37.4(\mathrm{~d}), 47.9(\mathrm{~d}), 62.0(\mathrm{t})$, $70.0(\mathrm{t}), 70.2(\mathrm{t}), 98.9(\mathrm{~d}), 114.3(\mathrm{t}), 138.9(\mathrm{~d})$; HRMS calcd for $\mathrm{C}_{17} \mathrm{H}_{30} \mathrm{O}_{2} \mathrm{~S}_{2} \mathrm{~m} / \mathrm{z} 330.1687$, found 330.1681 .

2-(2-(1-(Trimethylsilyl)-2,6-dithiacyclohexyl)ethyl)-5hexen-1-ol. To a solution of $640 \mathrm{mg}(1.94 \mathrm{mmol})$ of 39 in 2 $\mathrm{mL}$ of $\mathrm{THF}$ cooled at $0{ }^{\circ} \mathrm{C}$ was added dropwise over $10 \mathrm{~min}$ a solution of $1.50 \mathrm{~N}$ n-butyllithium in hexane $(1.95 \mathrm{~mL}, 2.94$ $\mathrm{mmol})$. The resulting solution was stirred at the same temperature for $20 \mathrm{~min}$ followed by the addition of a solution of $0.325 \mathrm{~mL}$ ( $2.55 \mathrm{mmol})$ of chlorotrimethylsilane in $1 \mathrm{~mL}$ of THF. The reaction mixture was stirred at $0{ }^{\circ} \mathrm{C}$ for $2 \mathrm{~h}$ and then partitioned between $100 \mathrm{~mL}$ of ether and $100 \mathrm{~mL}$ of water. The ether layer was washed with brine $(100 \mathrm{~mL})$, dried $\left(\mathrm{MgSO}_{4}\right)$, and concentrated. The brown liquid obtained was dissolved in $5 \mathrm{~mL}$ of methanol with the addition of a few crystals of $p$-toluenesulfonic acid monohydrate and stirred at room temperature for $2 \mathrm{~h}$. Two drops of triethylamine was added to the reaction mixture, and the resulting solution was concentrated. The resulting liquid was chromatographed over silica gel (eluted with hexane/ethyl acetate, 8/2) to give 507 $\mathrm{mg}(82 \%)$ of the alcohol as a pale yellow liquid: IR (neat) 3414 , $1633 \mathrm{~cm}^{-1}$; ${ }^{1} \mathrm{H}$ NMR $(200 \mathrm{MHz}) \delta 0.17(\mathrm{~s}, 9 \mathrm{H}), 1.35-1.60(\mathrm{~m}$, $5 \mathrm{H}), 1.75-2.28(\mathrm{~m}, 7 \mathrm{H}), 2.43(\mathrm{dt}, \mathrm{J}=14,4 \mathrm{~Hz}, 2 \mathrm{H}), 3.00$ (ddd, J $=14,12,4 \mathrm{~Hz}, 2 \mathrm{H}), 3.58(\mathrm{~d}, \mathrm{~J}=4 \mathrm{~Hz}, 2 \mathrm{H}), 4.94(\mathrm{br}$ $\mathrm{d}, \mathrm{J}=10 \mathrm{~Hz}, 1 \mathrm{H}), 5.00(\mathrm{br} \mathrm{d}, \mathrm{J}=17 \mathrm{~Hz}, 1 \mathrm{H}$ ), 5.80 (ddt, J = 17, 10, $7 \mathrm{~Hz}, 1 \mathrm{H}) ;{ }^{13} \mathrm{C}$ NMR $(50 \mathrm{MHz}) \delta-2.4(\mathrm{q}), 23.4(\mathrm{t}), 25.1$ $(\mathrm{t}), 28.5(\mathrm{t}), 30.2(\mathrm{t}), 31.2(\mathrm{t}), 34.3(\mathrm{t}), 38.9(\mathrm{~s}), 40.5(\mathrm{~d}), 65.3(\mathrm{t})$, 114.6 (t), 138.7 (d); HRMS calcd for $\mathrm{C}_{15} \mathrm{H}_{30} \mathrm{OS}_{2} \mathrm{Si} \mathrm{m} / \mathrm{z} 318.1507$, found 318.1512.

4-B romomethyl-1-trimethylsilyl-7-octen-1-one (40a). To a solution of $259 \mathrm{mg}(0.814 \mathrm{mmol})$ of 2-(2-(2-(trimethylsilyl)2,6-dithiacyclohexyl)ethyl)-5-hexen-1-ol and $0.17 \mathrm{~mL}(1.22$ $\mathrm{mmol}$ ) of triethylamine in $1 \mathrm{~mL}$ of dichloromethane at $0{ }^{\circ} \mathrm{C}$ was added $94 \mu \mathrm{L}(1.22 \mathrm{mmol})$ of methanesulfonyl chloride. The resulting mixture was stirred at $0{ }^{\circ} \mathrm{C}$ for $30 \mathrm{~min}$ and then partitioned between $50 \mathrm{~mL}$ of ether and $50 \mathrm{~mL}$ of water. The ether phase was washed with brine $(50 \mathrm{~mL})$, dried $\left(\mathrm{MgSO}_{4}\right)$, and concentrated. The resulting yellow liquid was dissolved in $2 \mathrm{~mL}$ of dry acetone and stirred with $139 \mathrm{mg}(1.60 \mathrm{mmol})$ of lithium bromide at $80^{\circ} \mathrm{C}$ for $2 \mathrm{~h}$. The resulting mixture was partitioned between $50 \mathrm{~mL}$ of dichloromethane and $50 \mathrm{~mL}$ of water. The organic layer was dried $\left(\mathrm{MgSO}_{4}\right)$ and concentrated to give a brown liquid. To the liquid and $121 \mathrm{mg}(1.44 \mathrm{mmol})$ of sodium bicarbonate in a mixture of $2 \mathrm{~mL}$ of acetonitrile, 2 $\mathrm{mL}$ of THF, and $1 \mathrm{~mL}$ of water was added over $5 \mathrm{~min}$ a solution of $585 \mathrm{mg}$ (1.36 mmol) of bis(trifluoroacetoxy)iodobenzene in $2 \mathrm{~mL}$ of acetonitrile. The resulting mixture was stirred at room temperature for $5 \mathrm{~min}$ and then partitioned between $50 \mathrm{~mL}$ of dichloromethane and $50 \mathrm{~mL}$ of water. The organic layer was dried $\left(\mathrm{MgSO}_{4}\right)$ and concentrated. The residual oil was chromatographed over silica gel (eluted with hexane/ethyl acetate, 96/4) to give $126 \mathrm{mg} \mathrm{(54 \% )}$ of $\mathbf{4 0 a}$ as a pale yell ow liquid: IR (neat) $1633 \mathrm{~cm}^{-1} ;{ }^{1} \mathrm{H}$ NMR $(200 \mathrm{MHz}) \delta 0.19(\mathrm{~s}, 9 \mathrm{H}), 1.38-$ $1.68(\mathrm{~m}, 5 \mathrm{H}), 1.98-2.12(\mathrm{~m}, 2 \mathrm{H}), 2.44-2.73(\mathrm{~m}, 2 \mathrm{H}), 3.40(\mathrm{~d}$, $\mathrm{J}=4 \mathrm{~Hz}, 2 \mathrm{H}), 4.90-5.06(\mathrm{~m}, 2 \mathrm{H}), 5.76(\mathrm{ddt}, \mathrm{J}=17,10,7$ $\mathrm{Hz}, 1 \mathrm{H}) ;{ }^{13} \mathrm{C}$ NMR $(50 \mathrm{MHz}) \delta-3.2(\mathrm{q}), 24.9(\mathrm{t}), 30.7$ (t), 31.7 $(\mathrm{t}), 38.2(\mathrm{~d}), 38.5(\mathrm{t}), 45.1(\mathrm{t}), 115.0(\mathrm{t}), 138.1(\mathrm{~d}), 247.4(\mathrm{~s})$; HRMS calcd for $\mathrm{C}_{15} \mathrm{H}_{23}{ }^{79} \mathrm{BrOSi} \mathrm{m} / \mathrm{z} 290.0701$, found 290.0707 .

5-B romomethyl-1-trimethylsilyl-8-nonen-1-one (43a). To a solution of $608 \mathrm{mg}(3.16 \mathrm{mmol})$ of 41 a in $6 \mathrm{~mL}$ of THF cooled at $0{ }^{\circ} \mathrm{C}$ was added dropwise over $5 \mathrm{~min}$ a solution of $1.56 \mathrm{~N}$ n-butyllithium in hexane $(2.40 \mathrm{~mL}, 3.74 \mathrm{mmol})$. The resulting mixture was stirred at $0{ }^{\circ} \mathrm{C}$ for $30 \mathrm{~min}$ and then 
added to a solution of $885 \mathrm{mg}(3.11 \mathrm{mmol})$ of $\mathbf{4 2}$ cooled at 0 ${ }^{\circ} \mathrm{C}$. The reaction mixture was stirred at $0{ }^{\circ} \mathrm{C}$ for $5 \mathrm{~h}$ and then partitioned between $100 \mathrm{~mL}$ of ether and $40 \mathrm{~mL}$ of water. The organic layer was washed with brine $(20 \mathrm{~mL})$, dried $\left(\mathrm{MgSO}_{4}\right)$, and concentrated in vacuo. The residual oil, $800 \mathrm{mg}$ of Celite, and $240 \mathrm{mg}$ ( $3.11 \mathrm{mmol}$ ) of sodium bicarbonate were mixed in $10 \mathrm{~mL}$ of acetonitrile and $2 \mathrm{~mL}$ of dichloromethane. The resulting mixture was cooled at $-20{ }^{\circ} \mathrm{C}$, following which a

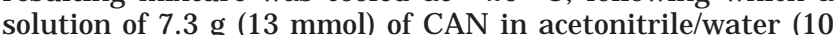
$\mathrm{mL} / 1 \mathrm{~mL}$ ) was added over a period of $2 \mathrm{~min}$. The resulting mixture was stirred at $-20{ }^{\circ} \mathrm{C}$ for $10 \mathrm{~min}$, filtered, and partitioned between $60 \mathrm{~mL}$ of ether and $30 \mathrm{~mL}$ of water. The organic layer was washed with brine $(20 \mathrm{~mL})$, dried $\left(\mathrm{MgSO}_{4}\right)$, and concentrated in vacuo. The residual oil was chromatographed over silica gel (eluted with hexane/ethyl acetate, 98/ 2) to give $290 \mathrm{mg}$ (31\%) of $\mathbf{4 3 a}$ as a pale yellow oil: IR (neat) $1636 \mathrm{~cm}^{-1} ;{ }^{1} \mathrm{H}$ NMR $(300 \mathrm{MHz}) \delta 0.15(\mathrm{~s}, 9 \mathrm{H}), 1.18-1.62(\mathrm{~m}$, $9 \mathrm{H}), 1.92-2.08(\mathrm{~m}, 2 \mathrm{H}), 2.57(\mathrm{t}, \mathrm{J}=6.9 \mathrm{~Hz}, 2 \mathrm{H}), 3.40(\mathrm{~d}, \mathrm{~J}$ $=4.4 \mathrm{~Hz}, 2 \mathrm{H}), 4.93(\mathrm{br} \mathrm{d}, \mathrm{J}=10 \mathrm{~Hz}, 1 \mathrm{H}), 4.98(\mathrm{br} \mathrm{d}, \mathrm{J}=17$ $\mathrm{Hz}, 1 \mathrm{H}), 5.75$ (ddt, J = 17, 10, $7 \mathrm{~Hz}, 1 \mathrm{H}) ;{ }^{13} \mathrm{C}$ NMR $(50 \mathrm{MHz})$ $\delta-3.2,18.9,30.7,31.5,32.0,38.7,38.8,48.3,114.8,138.1$; HRMS calcd for $\mathrm{C}_{13} \mathrm{H}_{25}{ }^{79} \mathrm{BrOSi} \mathrm{m} / \mathrm{z} 304.0858$, found 304.0851 .

General Procedure for Radical Cyclizations of Bromoacylsilanes 40, 43, 45, and 47. To a refluxing benzene (10-mL) solution of the bromoacylsilane $(1 \mathrm{mmol})$ was added via syringe pump over $1 \mathrm{~h}$ a benzene (10-mL) solution of tributyltin hydride $(1.2-1.5 \mathrm{mmol})$ and AI BN $(0.05 \mathrm{mmol})$. The resulting solution was heated at $80{ }^{\circ} \mathrm{C}$ for $1 \mathrm{~h}$ more and concentrated in vacuo. To the residual liquid was added a few drops of wet triethylamine, ${ }^{35}$ and the resulting mixture was chromatographed over silica gel (eluted with hexane/ethyl acetate) to isolate the products. The results are shown in Tables 1, 4, 6, and 7. The cyclization of bromoacylsilane $\mathbf{4 0 c}$ is shown below as an example. 3154.

(35) Curran, D. P.; Chang, C.-T. J . Org. Chem. 1989, 54, 3140-
Radical Cyclization of 40c. cis/trans-3-(3-Butenyl)cyclopentylmethyldiphenylsilyl Ether (48c) and cis/ trans-3-(3-Methylcyclopentyl)-1-(methyldiphenylsilyl)propan-1-one (50c). According to the general procedure for radical cyclization, starting from $394 \mathrm{mg}(0.95 \mathrm{mmol})$ of $\mathbf{4 0 c}$, $0.31 \mathrm{~mL}(1.14 \mathrm{mmol})$ of tributyltin hydride, and $7.7 \mathrm{mg}(0.047$ $\mathrm{mmol}$ ) of AIBN, we obtained $249 \mathrm{mg}(78 \%)$ of $48 \mathrm{c}$ (cis/trans = $53 / 47$ ) as a colorless liquid and $38 \mathrm{mg}(12 \%)$ of $\mathbf{5 0 c}$ (cis/trans $=1 / 2$ ) as a colorless liquid. 48c: IR (neat) $1634 \mathrm{~cm}^{-1} ;{ }^{1} \mathrm{H} N M R$ $(300 \mathrm{MHz}) \delta 0.62(\mathrm{~s}, 3 \mathrm{H}), 0.98-2.25(\mathrm{~m}, 11 \mathrm{H}), 4.28(\mathrm{q}, \mathrm{J}=$ $6.0 \mathrm{~Hz}, 0.53 \mathrm{H}$, cis isomer), 4.32-4.42 (m, $0.47 \mathrm{H}$, trans isomer), 4.85-5.05 (m, $2 \mathrm{H}), 5.68-5.91(\mathrm{~m}, 1 \mathrm{H}), 7.28-7.52$ $(\mathrm{m}, 6 \mathrm{H}), 7.50-7.62(\mathrm{~m}, 4 \mathrm{H})$; HRMS calcd for $\mathrm{C}_{22} \mathrm{H}_{28} \mathrm{OSi} \mathrm{m} / \mathrm{z}$ 336.1909, found 336.1903. 50c: IR (neat) $1633 \mathrm{~cm}^{-1} ;{ }^{1} \mathrm{H} N M R$ $(200 \mathrm{MHz}) \delta 0.74(\mathrm{~s}, 3 \mathrm{H}), 0.88(\mathrm{~d}, \mathrm{~J}=6.4 \mathrm{~Hz}, 2 \mathrm{H}$, trans isomer), $0.91(\mathrm{~d}, \mathrm{~J}=5.4 \mathrm{~Hz}, 1 \mathrm{H}$, cis isomer $), 0.95-1.12(\mathrm{~m}, 2$ $\mathrm{H}), 1.15-1.28(\mathrm{~m}, 2 \mathrm{H}), 1.44$ (quintet, J $=7.3 \mathrm{~Hz}, 2 \mathrm{H}), 1.56-$ $2.08(\mathrm{~m}, 4 \mathrm{H}), 2.63(\mathrm{t}, \mathrm{J}=7.4 \mathrm{~Hz}, 2 \mathrm{H}), 7.30-7.46(\mathrm{~m}, 6 \mathrm{H})$, 7.54-7.62 (m, $4 \mathrm{H}$ ); HRMS calcd for $\mathrm{C}_{21} \mathrm{H}_{25} \mathrm{OSi} \mathrm{m} / \mathrm{z} 321.1675$, found 321.1673 .

Acknowledgment. Financial support from the National Science Council of the Republic of China is gratefully acknowledged.

Supporting Information Available: Details of compound characterization of $40 b, c, 43 b-j, 45 a-d, 46,47 a-c, 48 a, b$, 49, 50a, b, trans-53a, c, d, f, g, i, j, cis-53b, c, e, f, g, i, j, cis-54, trans-54, 55a-g, 56d, e, g, 57c, 58e, cis-59a-d, trans$59 b-d, 61 a-d, 63-65,66 a, c, 67 a, b, 68 c$ and $69 a-c$, and ${ }^{1} \mathrm{H}$ and ${ }^{13} \mathrm{C}$ NMR spectra of new compounds (77 pages). This material is contained in libraries on microfiche, immediately follows this article in the mi crofilm version of the journal, and can be ordered from the ACS; see any current masthead page for ordering information.

J O982079K 